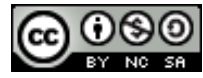

https://doi.org/10.31743/abmk.11784

KS. MARIUSZ TRĄBA* - KRAKÓW

\title{
OPIS PARAFII ŚW. STANISŁAWA BISKUPA \\ I MECCZENNIKA W CZELADZI Z 1791 ROKU \\ (FRAGMENT NIEODNALEZIONEJ WIZYTACJI DEKANATU SIE- WIERSKIEGO DIECEZJI KRAKOWSKIEJ Z LAT 90. XVIII WIEKU)
}

\section{Streszczenie}

W 1846 r. proboszczem parafii św. Stanisława w Czeladzi został mianowany ks. Wojciech Janecki. Okazało się wówczas, że parafia nie posiada aktualnego inwentarza dóbr i praw majątkowych. W poszukiwaniu tego dokumentu zwrócono się do Konsystorza Generalnego Diecezji Krakowskiej. Pomimo poszukiwań dokumentu takiego nie odnaleziono. W archiwum Konsystorza odkryto jedynie dokument opisujący miasto Czeladź oraz parafię czeladzką sporządzony w 1791 r. Jego odpis przesłano do Konsystorza Diecezji Krakowskiej w Kielcach. Ten właśnie dokument jest przedmiotem niniejszego opracowania.

Prawdopodobnie dokument pod nazwą Opisanie Kościoła i Parafii Miasteczka Czeladź z 1791 r. stanowi fragment większej całości; być może wizytacji dekanatu siewierskiego $\mathrm{z}$ tego okresu. Wskazuje na to jego treść oraz struktura będąca powtórzeniem tego typu dokumentów z końca XVIII wieku, np. wizytacji sąsiedniego dekanatu bytomskiego z lat 1792-1793. Dotychczasowe poszukiwania $\mathrm{w}$ archiwach kościelnych i państwowych nie przyniosły pozytywnych rezultatów w zakresie odszukania źródeł potwierdzających przeprowadzenie owej wizytacji.

Publikowany dokument stanowi jedno z najważniejszych źródeł dotyczących dziejów Czeladzi w końcowym okresie istnienia Rzeczypospolitej szlacheckiej. Jego autor podaje dokładne dane dotyczące parafii oraz kościoła w Czeladzi w ostatnich latach przed zaborami. Należy podkreślić, że dokument ten nie został wykorzystany w dotychczasowych badaniach nad dziejami miasta Czeladzi.

Słowa kluczowe: parafia św. Stanisława; Rzeczpospolita przedrozbiorowa; dekanat siewierski; Czeladź; XVIII wiek; wizytacje kanoniczne; diecezja krakowska

* Ks. Mariusz Trąba - Instytut Historii, Uniwersytet Papieski Jana Pawła II w Krakowie; e-mail: mariusz.traba@upjp2.edu.pl

https://orcid.org/0000-0001-5836-9052 
Parafia św. Stanisława Biskupa i Męczennika w Czeladzi od 1992 r. znajduje się $\mathrm{w}$ granicach diecezji sosnowieckiej. Pierwsza wzmianka pisana o istnieniu kościoła w Czeladzi pochodzi z 1260 r. Świątynia została ufundowana przez księcia opolskiego Władysława. Prawdopodobnie wraz z fundacją i budową kościoła wyznaczono okręg parafialny, tworząc w ten sposób parafię w Czeladzi. Od chwili swego powstania aż do XIX wieku należała ona do diecezji krakowskiej¹.

Parafia nie posiada jak do tej pory swej własnej naukowej monografii. W monografii Czeladzi, która ukazała się w okresie Polski Ludowej, wiadomości o życiu religijnym tego miasta są mniej niż skromne. Uwypuklono w tym - niemniej bardzo cennym opracowaniu - rewolucyjne tradycje miasta oraz jego rozwój po 1945 r. ${ }^{2}$ Po 1989 r. popularnonaukową monografię kościoła czeladzkiego i parafii wydał Czesław Ryszka ${ }^{3}$. Wiele cennych, źródłowych informacji na temat dziejów życia religijnego Czeladzi przyniosła dopiero nowa monografia miasta, która ukazała się w 2012 r. pod redakcją Jana Drabiny. Należy zaznaczyć, że jest to do tej pory jedyne tak obszerne opracowanie dziejów miejscowości, a jednocześnie tak ściśle oraz wieloaspektowo ukazujące rozwój i przemiany życia religijnego jego mieszkańców ${ }^{4}$. Szeroka panorama dziejów parafii w okresie II wojny światowej została zaprezentowana $\mathrm{w}$ materiałach źródłowych zebranych i opracowanych przez Mariusza Trąbę 5 .

Opracowany i publikowany poniżej dokument stanowi odpis wizytacji parafii w Czeladzi dokonanej w 1791 r. Prawdopodobnie była ona częścią wizytacji całego ówczesnego dekanatu siewierskiego, który w wyniku zmian granicznych pod koniec XVIII wieku dostał się pod panowanie pruskie. Świadczyć o tym może zarówno forma publikowanego źródła, czyli katalog opisanych w dokumencie zagadnień, jak też czas jego powstania. Józef Pater, opracowując protokoły wizytacyjne sąsiedniego dekanatu bytomskiego z 1792 i 1793 r., sugeruje, że podobna wizytacja mogła zostać przeprowadzona w tym samym czasie także w dwóch innych dekanatach diecezji krakowskiej, które po 1794 r. znalazły się pod panowaniem pruskim - dekanacie siewierskim i dekanacie pilickim ${ }^{6}$. Oczywiście należy uwzględnić tu dwojaki kontekst sytuacji wymienionych dekanatów. Z jednej strony - stanowiły one części tej samej diecezji krakowskiej i podlegały władzy biskupa krakowskiego; z drugiej jednak - znajdowały się w odmiennej sytuacji politycznej. Dekanat bytomski od 1742 r. leżał w granicach państwa pruskiego i podlegał zasadom pruskiej polityki wyznaniowej; z kolei zaś dekanaty siewier-

${ }^{1}$ J. Rajmna, Czeladź do końca XVI wieku, w: Historia Czeladzi, t. 1, red. J. Drabina, Czeladź 2012, s. 109-119; B. Kumor, Dzieje diecezji krakowskiej do roku 1795, t. 4, Kraków 2002, s. 193.

${ }^{2}$ K. Sarna, Czeladź. Zarys rozwoju miasta, Katowice 1977.

${ }^{3}$ Cz. Ryszka, Klejnot Czeladzi. Kościół św. Stanisława Biskupa i Męczennika, Bytom 1997.

${ }^{4}$ Historia Czeladzi, t. 1-2, red. J. Drabina, Czeladź 2012.

${ }^{5}$ M. Trąba, Czeladź w latach II wojny światowej (1939-1945). Źródła i materiały z archiwów kościelnych, Katowice 2011; recenzja: A. Rejdak, Czeladź w latach II wojny światowej (1939-1945) ks. Mariusza Trąby. Sprostowania i uwagi, „Zeszyty Czeladzie”, 17 (2012) s. 45-50.

${ }^{6}$ Protokoły wizytacyjne dekanatu bytomskiego z lat 1792-1793, wydał J. Pater, Poznań-Wrocław 2003, s. 12. 
ski i pilicki w omawianym okresie, czyli przed 1795 r., leżały w granicach Rzeczypospolitej i podlegały jej prawu i polityce wyznaniowej.

Źródła wizytacyjne do dziejów diecezji krakowskiej w XVIII wieku są niezwykle bogate. Są to źródła niezwykle dokładne, bardzo cenne dla poznania wielu aspektów dziejów terenów tej diecezji. Często dokumentacja ta ma charakter unikatowy i jest często wykorzystywana przez badaczy? ${ }^{7}$. Wydaje się więc, że ustalenie faktu nieznanej i niewspominanej dotąd wizytacji może ukierunkować tychże badaczy w dalszych poszukiwaniach, publikacja zaś omawianego dokumentu mieć ważne znaczenie dla poznania dziejów wschodniej Małopolski tuż przed trzecim rozbiorem Rzeczypospolitej.

Nie znany jest oryginał wizytacji dekanatu siewierskiego z 1791 r. ani żaden przekaz, który potwierdzałby jej przeprowadzenie. Zachowany i publikowany dokument stanowi ważny argument za tezą, że wizytacja tego typu została przeprowadzona i że dokonano tego w 1791 r., czyli jeszcze w okresie istnienie suwerennej Rzeczypospolitej. Kwerenda archiwalna dokonana przez autora opracowania m.in. w Archiwum Kurii Metropolitalnej w Krakowie, Archiwum Kapituły Metropolitalnej w Krakowie, Archiwum Diecezjalnym w Kielcach i Archiwum Archidiecezji Częstochowskiej w celu odnalezienia innych śladów tej wizytacji nie przyniosła pozytywnego rezultatu. Wydawałoby się jednak dziwne, gdyby tego typu wizytację przeprowadzono tylko w jednej parafii dekanatu; i to parafii nie wyróżniającej się w jakiś szczególny sposób spośród innych. Nie ma też mowy o błędnym datowaniu dokumentu, np. w chwili jego kopiowania. Rok 1791, jako czas powstania Opisania Kościoła..., jest poświadczony kilkakrotnie w sposób niebudzący wątpliwości. Jednocześnie sam dokument nie zawiera danych dotyczących wydarzeń po $1791 \mathrm{r}$.

Wątpliwości w powyższym względzie może budzić jedynie ostatni akapit dokumentu poświęcony dochodom wikariuszy parafii w Czeladzi. Został on do niego dopisany na końcu innym charakterem pisma i odmiennie niż cały dokument, który został sporządzony w języku polskim, tylko ten fragment jest w całości zapisany w języku łacińskim. Charakterystyczne jest, że tylko w tym akapicie wspomina się o Wysokim Urzędzie we Wrocławiu. W 1791 r. dekanat siewierski podlegał władzy biskupów krakowskich. Choć wojska pruskie stacjonowały w zachodniej Małopolsce już od wiosny 1794 r., to dopiero na mocy postanowień traktatów rozbiorowych z $1795 \mathrm{r}$. oficjalnie obszary te (w tym i miasto Czeladź) stały się częścią państwa pruskiego. Fakt ten stał się początkiem nowego etapu starań władz pruskich o przejęcie władzy nad dekanatami znajdującymi się w granicach ich państwa, a podległymi administracyjnie biskupowi w Krakowie ${ }^{8}$.

${ }^{7}$ Por. S. Litak, Kościót łaciński w Rzeczypospolitej około 1772 roku. Studium administracyjne, Lublin 1996; J. Szczepaniak, Duchowieństwo diecezji krakowskiej w XVIII wieku. Studium propozograficzne, Kraków 2010, s. 511-530.

${ }^{8}$ D. Nawrot, W latach burzliwych zmian politycznych (1795-1831), w: Historia Czeladzi, t. 1, s. 275-277; tenże, Powstanie na Nowym Śląsku w 1806 i 1807 roku. Uźródeł Zagłębia Dąbrowskiego, Czeladź 2016, s. 9-28; J. Związek, Przynależność kościelna pogranicza Wielko- i Małopolski ze Śląskiem, „Prace Naukowe Wyższej Szkoły Pedagogicznej w Częstochowie”, seria: „Zeszyty Historyczne", 2 (1994) s. 87-89; tenże, Utrata jurysdykcji przez biskupów krakowskich na Nowym 
Należy sądzić, że ostatni akapit publikowanego tekstu został skopiowany z innego dokumentu pochodzącego już z okresu władzy pruskiej nad Czeladzią, czyli z lat po 1794 r. Dołączono go zapewne po to, aby wyjaśnić ważną kwestię podziału dochodów parafialnych, a przecież to najbardziej interesowało osoby poszukujące danych na temat uposażenia parafii.

W jakich okolicznościach powstał dokument z 1791 r.? Pewne znaczenie mogły tu mieć wydarzenia polityczne związane $\mathrm{z}$ utratą przez biskupów krakowskich władzy nad księstwem siewierskim. Zostało ono zakupione 24 grudnia 1443 r. przez biskupa krakowskiego Zbigniewa Oleśnickiego od księcia Wacława Cieszyńskiego. W dniu 11 czerwca 1790 r. uchwałą sejmu polskiego księstwo siewierskie (na terenie którego znajdowały się miasto i parafia Czeladź), stanowiące własność biskupów krakowskich, zostało włączone do Rzeczypospolitej. Było to faktyczne zakończenie trwającego od ponad roku procesu legislacyjnego i prawnego, będącego dziełem Sejmu Wielkiego ${ }^{9}$. Nie sposób stwierdzić, czy to te właśnie ważne wydarzenia polityczne miały związek z wizytacją parafii czeladzkiej w 1791 r. Może w sytuacji, kiedy dokonywano ważnych zmian w sprawach własnościowych oraz polityczno-społecznych odnośnie tego obszaru, włodarze biskupstwa krakowskiego nie podjęli decyzji, aby dokonać lustracji stanu prawnego i majątkowego parafii na tym terenie? Niestety do chwili odnalezienia dokumentów potwierdzających chociażby kto i z czyjego polecenia oraz na jakim obszarze dokonał tej wizytacji, nie sposób jednoznacznie określić, jaki były jej cel i założenia.

Zdecydowanie dokładniejsze informacje istnieją na temat powstania odpisu dokumentu z 1791 r., co nastąpiło w styczniu 1847 r. W 1846 r. proboszczem parafii św. Stanisława BM w Czeladzi został mianowany ks. Wojciech Janecki $(† 1864)$. Objął on ów urząd po zmarłym księdzu Jakubie Krupińskim (17601845), który funkcję proboszcza czeladzkiego pełnił przeszło czterdzieści lat (1801-1845) ${ }^{10}$. W związku z objęciem beneficjum przez nowego włodarza pojawił się problem, gdzie znajduje się inwentarz kościoła oraz parafii. Poszukiwania tego dokumentu, który zawierał m.in. opis należnych proboszczowi dochodów, było zrozumiałe. Ks. W. Janecki natychmiast po objęciu urzędu proboszcza rozpoczął bowiem zdecydowane działania w celu restytucji należnych parafii i probostwu praw majątkowych, co doprowadziło do długotrwałych sporów pomiędzy nim a okolicznymi włościanami, tak z samej Czeladzi, jak i z sąsiednich Wojkowic Komornych. Władze konsystorskie z Kielc zwróciły się z prośbą do Konsystorza Generalnego diecezji krakowskiej z prośbą o przeszukanie archiwów i odnalezienie inwentarz kościoła, zgodnie z którym przyjmował beneficjum i urząd zmarły

Śląsku i w okręgu częstochowskim, „Analecta Cracoviensia”, 32 (2000) s. 401-413; W. Wlaźlak, Komisariat Siewierski w diecezji wrocławskiej (1797-1818), „Śląski Kwartalnik Historyczny Sobótka", 58 (2003) z. 3, s. 257-272.

${ }^{9}$ Por. B. Kumor, Dzieje diecezji, t. 1, Kraków 1998, s. 261-267; K.Z. Żelazny, Księstwo Siewierskie. Prawo i ustrój a zakres suwerenności względem Korony Królestwa Polskiego, Katowice 2016, s. 119-131.

${ }^{10}$ Por. M. Trąba, Stosunki wyznaniowe, w: Historia Czeladzi, t. 1, red. J. Drabina, Czeladź 2012, s. $479-480$. 
ks. J. Krupiński. Pomimo poszukiwań w archiwum konsystorza w Krakowie nie udało się odnaleźć takiego dokumentu. Natrafiono jedynie na opis kościoła i parafii czeladzkiej z 1791 r., którego odpis 5 stycznia 1847 r. przesłano władzom konsystorskim w Kielcach, tłumacząc,

że zaś X. Krupiński blisko lat trzydzieści [sic!] rządził tem beneficjum opis przeto załączony w braku innych dowodów do weryfikacji posłużyć może jako niezbyt odległy od epoki objęcia tego beneficjum przez X. Krupińskiego ${ }^{11}$.

Odpis dokumentu trafił do zbioru akt parafii Czeladź w Konsystorzu Diecezjalnym w Kielcach. Z Kielc akta konsystorskie parafii, które w 1925 r. znalazły się $\mathrm{w}$ granicach nowopowstałej diecezji częstochowskiej, zostały przekazane do Częstochowy. Aktualnie stanowią one część zasobu Archiwum Archidiecezji Częstochowskiej ${ }^{12}$.

Rękopiśmienny dokument liczy 13 stron. Na stronie tytułowej znajduje się napis wykonany atramentem: Opisanie Kościoła i Parafii Miasteczka Czeladź. Ołówkiem dopisano datę $1791 \mathrm{r}$. W dokumencie nie określono, kto go sporządził i z czyjego polecenia. Jedynie na zakończenie dokumentu widnieje potwierdzenie zgodności kopii z oryginałem. Sekretarz, najprawdopodobniej Konsystorza Jeneralnego w Krakowie, ks. Romer 3/15 stycznia 1847 r. poświadczył, że treść dokumentu będącego kopią była zgodna z treścią oryginału, który przechowywany był w aktach Konsystorza Jeneralnego diecezji krakowskiej. Dokument oryginalny był papierowy i nie posiadł stempla ${ }^{13}$. Kopia Opisania Kościoła ... jest napisana czytelnie i wyraźnie. Staranność zapisu maleje w dalszych partiach dokumentu, co świadczy, że przepisująca go osoba była zmęczona lub chciała jak najszybciej zakończyć prace nad jego kopiowaniem.

Przy opracowaniu niniejszego dokumentu zastosowano zasady Instrukcji wydawniczej dla źródet historycznych od XVI do połowy XIX wieku ${ }^{14}$. Jednocześnie wykorzystano doświadczenia badaczy, którzy publikowali teksty źródłowe tego

${ }^{11}$ AACz, Akta Konsystorza Kieleckiego, syg. KK 70: Akta Konsystorza Generalnego części diecezji krakowskiej w Królestwie Polskim tyczące się kościoła w Czeladzi 1791-1924, k. 245. Pismo Konsystorza Jeneralnego Dyecezyi Krakowskiej do Konsystorza tejże Diecezyi w Kielcach (Kraków, 5 I 1847).

12 Por. W. Wlaźlak, Zasoby akt konsystorskich w Archiwum Archidiecezji Częstochowskiej, „Częstochowskie Studia Teologiczne” 33 (2005), s. 193-209; tenże, Inwentarz ksiąg konsystorskich Archiwum Archidiecezji Częstochowskiej im. ks. Walentego Patykiewicza w Częstochowie, „Rocznik Towarzystwa Genealogicznego Ziemi Częstochowskiej”, 2 (2011) s. 111-138.

${ }^{13} \mathrm{AACz}$, Akta Konsystorza Kieleckiego, syg. KK 70, k. $261 \mathrm{a}$.

${ }^{14}$ Instrukcja wydawnicza dla źródet historycznych od XVI do połowy XIX wieku, red. K. Lepszy, Wrocław 1953. 
typu, takich jak Waldemar W. Żurek ${ }^{15}$, Małgorzata Karkocha ${ }^{16}$, Maria Taszycka ${ }^{17}$, Tomasz J. Filozof ${ }^{18}$, Marcin Janakowski ${ }^{19}$, Agata Kaczmarek i Agata Młyńska ${ }^{20}$, Anzelm Weiss ${ }^{21}$ oraz niezwykle wartościowe opracowania Ireny Turnau ${ }^{22}$ i Iwony Żuraszek-Ryś23 ${ }^{23}$.

\section{Opisanie Kościoła i Parafii Miasteczka Czeladzi $[1791 \text { r. }]^{24}$}

\section{Opisanie kościoła i parafii miasteczka Czeladzi 1791.}

\section{De Ecclesia et Parochia ${ }^{25}$}

Kościół parafialny miasteczka Czeladzi w Księstwie Siewierskim, przy granicy śląskiej, struktury starodawnej, od parafianów, pod tytułem ś. Stanisława Biskupa i Męczennika fundowany i wymurowany.

${ }^{15}$ W.W. Żurek, Inwentarz kościoła parafialnego w Kiwatyczach z1853 roku, „Archiwa, Biblioteki i Muzea Kościelne”, 99 (2013) s. 317-333; tenże, Inwentarz parafii Świętego Michała Archanioła w Iwieńcu z 1939 roku, „Resovia Sacra”, 21 (2014) s. 503-531; tenże, Wizytacja kościoła parafialnego w Kosowie z 1844 roku, „Nasza Przeszłość” (dalej: NP), 124 (2015) s. 137-164; tenże, Wizytacja kościoła parafialnego w Dywinie w diecezji wileńskiej z 1867 roku, NP, 126 (2016) s. 265-290.

${ }^{16}$ M. Karkocha, Wystrój i wyposażenie kościoła parafialnego w Małogoszczu w świetle inwentarza z 1856 roku, „Przegląd Nauk Historycznych”, 16 (2017) z. 1, s. 325-362.

${ }^{17} \mathrm{M}$. Taszycka, Inwentarz szat liturgicznych i innych tkanin zabytkowych z kościoła św. Marka w Krakowie, NP, 71 (1989) s. 115-136.

${ }^{18}$ T.J. Filozof, Nieznany inwentarz parafii staromiejskiej z 1819 roku, „Prace Historyczno-Archiwalne", 14 (2004) s. 155-159.

${ }^{19}$ M. Janakowski, Inwentarz kościoła parafialnego w Chlewiskach z lat 1865-1866, „Z Dziejów Regionu i Miasta", 6 (2015) s. 119-151.

${ }^{20}$ A. Kaczmarek, A. Młyńska, Źródła do dziejów parafii w Szadku z roku 1825 - wizyta dziekańska i inwentarz parafialny, „Biuletyn Szadkowski”, 10 (2010) s. 199-217.

${ }^{21}$ A. Weiss, Akta wizytacyjne parafii Wolsztyn z 1777 roku, Lublin 2019.

${ }^{22}$ I. Turnau, Stownik ubiorów, tkanin, wyrobów pozatkackich, skóry, broń i klejnoty znane w Polsce od średniowiecza do poczatku XIX w., Warszawa 1999.

${ }^{23}$ I. Żuraszek-Ryś, Inwentarz skarbca katedry ormiańskiej we Lwowie z XVIII wieku jako źródto do leksykologii historycznej, „Acta Universitatis Lodziensis. Folia Linquistica”, 49 (2015) s. 115-124; taż, Który to ornat? O sposobach nominacji ornatów w inwentarzach skarbca archikatedralnego kościoła ormiańskiego we Lwowie, „Poznańskie Spotkania Językoznawcze”, 23 (2012) s. 301-317; taż, Pudełko Srebrne do Hostyi bez przykrywadła. O sposobach określania przedmiotów w inwentarzach kościelnych, „Poznańskie Studia Polonistyczne. Seria Językoznawcza”, 23 (2016), z. 1, s. 131-143; taż, Nazwy tkanin wschodniego pochodzenia w osiemnastowiecznej polszczyźnie (na przykładzie materiału z dwóch inwentarzy skarbca archikatedralnego kościoła ormiańskiego we Lwowie), w: Kontakty językowe w komunikowaniu, red. M. Steciąg, M. Adamczyk, M. Biszczanik, Zielona Góra 2016, s. 137-147.

${ }^{24} 1791$ r. - data została dopisana ołówkiem oraz innym charakterem pisma niż cały dokument.

${ }^{25}$ De Ecclesia et Parochia (łac.) - Odnośnie kościoła i parafii. 


\section{Erekcyi nie ma.}

Przez kogo konsekrowany pewności nie masz. Dzień jednak poświęcenia kościoła obchodzi się w niedzielę pierwszą po uroczystości Wszystkich Świętych.

Kościoł graniczy z parafiami: na wschod Słońca z będzińską w Koronie Polskiej, na zachód z kamieńską w Śląsku gornym, na południe z bogucką w Śląsku, na północ z grodziecką w Księstwie Siewierskim. Pobliższe miasteczka Czeladzi są miasta: na wschód Będzin o pół mile, na zachód Bytom o mile w Śląsku, na południe Mysłowice o milę także w Śląsku, na północ Siewierz o trzy mile. Obok tego miasteczka ku południowi płynie rzeka Brynnica ${ }^{26}$, wpada w Wisłę o 4 mile pod Oświęcimem; ta lubo dwie wioski parafialne pograniczne Śląska od kościoła dzieli, nigdy jednak przez swoje, osobliwie na wiosnę wylewy, trudnego przejścia parafianom na nabożeństwo nie sprawuje.

Kościół czeladzki zamyka w sobie prawem farnym 4 wsie i 5. miasteczko. 1. Woykowice Komorne. 2. Milejowice z Pustkowiem pod Borem. 3. Miasteczko Czeladź w Księstwie Siewierskim, w Śląsku górnym przy granicy 4. Siemianowice z Pustkowiami Czekaj, Sadzawki. 5 Przełajka z Kuznicą.

Dusz do spowiedzi wielkanocnej rachuje się 1428. Wszyscy zadosyć powinności swojej uczynili. A którzy prawu temu dla niedoskonałego rozumu niepodlegają, liczy się 503, między ktoremi jest kalwinka i Grek dysunit Winiarz z synem; wszystkich, o ktorych się ma pieczołowitość pasterską iest 1931.

Rozległość tej parafi od wschodu Słońca ku zachodowi pół mili; od południa ku północy ćwierć mile.

Kollator $^{27}$ kościoła, Jaśnie Oświecony Książe Siewierski Biskup Krakowski.

\section{De Eucharistia ${ }^{28}$}

Cyborium $^{29}$, w ktorym się chowa Sanctissimum ${ }^{30}$; lubo staroświecke, przystojnie pod zamknięciem utrzymuje się.

Odnawia się dwa lub trzy razy w miesiąc.

Wystawia się w Odpusty. Niepokalanego Poczęcia Maryi Panny. W Czwartek zapustny. Kazdą niedzielę na Pasyi Wielkiego Postut ${ }^{31}$. W Uroczystość S. Stanisława Biskupa i Męczennika. Przez eałą oktawę Bożego Ciała ${ }^{32}$. Na Dzien S. Anny. w Suche dni każdego Wtorku³.

${ }^{26}$ Brynnica - rzeka, współczesna nazwa: Brynica, prawy dopływ Czarnej Przemszy, na pewnym odcinku rzeka stanowi historyczną granicę pomiędzy Górnym Śląskiem a Zagłębiem Dąbrowskim oraz administracyjną granicę między Katowicami a Sosnowcem.

${ }^{27}$ Kolator - 1) przełożony kościelny udzielający beneficjum; 2) patron kościoła, któremu na zasadzie ius patronatum przysługiwało prawo prezenty na beneficjum lub urząd; często był to fundator kościoła lub jego spadkobiercy, którym przysługiwało prawo patronatu danej świątyni.

${ }^{28}$ De Eucharystia (łac.) - Odnośnie Eucharystii.

${ }^{29}$ Z kontekstu wynika, że w tym wypadku terminem „cyborium” określono tabernakulum, gdzie przechowywano Najświętszy Sakrament. Pojęcie to nie oznacza w powyższym dokumencie puszki na komunikanty, gdyż ta jest opisana i scharakteryzowana osobno poniżej.

${ }^{30}$ Sanctissimum (łac.) - Najświętszy Sakrament.

${ }^{31}$ Tekst wykreślony w dokumencie.

${ }^{32}$ Tekst wykreślony w dokumencie.

${ }^{33}$ Tekst wykreślony w dokumencie. 
Puszka, w ktorej się utrzymuje Sanctissimum srebrna, wyzłacana, konsekrowana, w sukienkę materjalną przyozdobiona. Do chorych iadąc, zachowuje się przepis Rytuału, przed ktorym z pobożności pali się Lampa.

\section{De Vase baptizmatis et Oleis Sacris ${ }^{34}$}

Krzcielnica z kamienia wyrobiona w czarny marmur pokostowana, wewnątrz ma kocioł, miedziany, wybielony, w ktorym się woda krzcielna zamyka; dwa razy w rok odnowiona, Sabbatho Sancto ${ }^{35}$ et Vigilia Pentecostes ${ }^{36}$. Przy tej jest piscina zaraz głęboko wyrobiona, gdzie się woda baptisatorum ${ }^{37}$ zlewa.

Dzieci do krztu ś. zwykły się zaraz przynosić, przy ktorych odbieraniu bywają podeszłe w leciech niewiasty, maiące wiadomosc, jak sobie w niebezpieczeństwie postąpić mają, i one w czasie potrzeby okrzcic.

Na Olea Sacra ${ }^{38}$, vascula ${ }^{39}$ cynowe, potrojne, a do chorych srebrne uzywają się, o które odnowienie w Wielką Sobotę i Świąteczną, każdego roku staranność zachowuje się.

\section{De Altaribus et eorum Suppellectili ${ }^{40}$}

W tym kościele znayduje się ołtarzy 4 konsekrowanych, każdy trzema obrusami nakryty, obrazami przystojnie przybrany. Żadnego nie masz cudami słynącego. 1 mo Wielki Ołtarz S. Stanisława Męczennika z mensą, murowany, konsekrowany. 2do Pocieszenia Matki Boskiej cum portatili ${ }^{41}$. W tym ołtarzu mieści się obraz Immaculata Conceptionis BVM ${ }^{42}$. 3tio ś. Anny z mensą murowany, konsekrowany, do ktorego jest bractwo tejże świętej. 4to W kaplicy jest ołtarz Miłosiernego Pana Jezusa cum portatili ${ }^{43}$, i z bractwem. W tym ołtarzu jest także obraz ś. Jana Nepomucena. W pałacu JM Pana Lazara Henkla ${ }^{44}$ grafa bytomskiego jest kaplica prywatna pod tą farą w Siemianowicach, w ktorej Msza ś. się odprawuje za indultem rzymskim do życia dziedzica, roku tysiącznego siedmsetnego siedem-

${ }^{34}$ De Vase baptizmatis et Oleis Sacris (łac.) - Odnośnie chrzcielnicy i Olejów Świętych.
${ }^{35}$ Sabbatho Sancto (łac.) - w Wielką Sobotę.
${ }^{36}$ Vigilia Pentecostes (łac.) - w Wigilię uroczystości Zasłania Ducha Świętego.
${ }^{37}$ Baptisatorum (łac.) - ochrzczonych.
${ }^{38}$ Olea Sacra (łac.) - Oleje Święte.
${ }^{39}$ Vasculum, -i - dosł. małe naczyńko; najczęściej tym terminem określa się małe naczynie z wodą, stojące w pobliżu tabernakulum i służące do obmycia palców np. po rozdawaniu Komunii św.; w tym wypadku małe naczynie na oleje święte.

${ }^{40}$ De Altaribus et eorum Suppellectili (łac.) - Odnośnie ołtarzy i ich sprzętów liturgicznych.

${ }^{41}$ Cum portatili (łac.) - z portatylem.

${ }^{42}$ Obraz Immaculatae Conceptionis Beatae Virginis Mariae (łac.) - obraz Niepokalanie Poczętej Najświętszej Maryi Panny.

${ }^{43}$ Cum portatili (łac.) - z portatylem.

${ }^{44}$ Łazarz III Henckel von Donnersmarck (1729-1805) - 1768-1805 właściciel Bytomia i Siemianowic; od 1793 r. piąty wolny pan Bytomia; rezydował w Siemianowicach; w swoich rozległych dobrach dbał o rozwój przemysłu i górnictwa; wspierał budowę kościołów parafialnych w Radzionkowie i Kochłowicach oraz kościoła minorytów w Bytomiu, gdzie ufundował kryptę grobową dla swej rodziny; por. A. Kuzio-Podrucki, Henckel von Donnersmarckowie - kariera i fortuna rodu, Bytom 2003, s. 60, 62-65, 67, 87, 95, 97-98. 
dziesiątego drugiego, dnia trzeciego czerwca w Krakowie w sądach zadwornych otrzymanym.

Kursu przy tym kościele nie masz.

Inwentarz niżej spisany sprzętów kościelnych.

De Reliquiis ${ }^{45}$

Przy tym kościele znajduje się relikwia ś. Anny.

\section{De Confraternitatibus et Indulgentiiis ${ }^{46}$}

Bractwo ś. Anny za przywilejem Roku Pańskiego tysiącznego szesćsetnego piędziesiątego pierwszego, dnia pierwszego lutego w Warszawie w konwencie WW. OO. Bernardynów danym, i roku tegoż dnia trzeciego marca w Krakowie w sądach zadwornych potwierdzonym, jest wprowadzone, z nabożeństwa parafianów utrzymuje się.

\section{De Fabrica Ecclesiae E7 $^{4}$}

Stan kościoła tego jest bardzo mizerny, a dla płytkich, i zmylonych fundamentów pustoszeje; pokryty gontami; ma wieżyczkę z sygnaturką w mniejszym chórze gątami pokrytą ${ }^{48}$. Podsiebitka ${ }^{49} \mathrm{z} \operatorname{tarcic}^{50}$ stara, spruchniała, z prostym malowaniem. Podłoga $\mathrm{z}$ tarcic stara, popsuta w większym chórze, w mnieyszym kamienna. Ściany tego koscioła dużo porysowane w pięciu miejscach ku wschodowi. Okien po całym kosciele $\mathrm{N}^{\text {ro }} 5$. W niektorych szyby ztłuczone sparsim ${ }^{51}$. Ławki wszystkie i formy prezbyteralne prostą robotą robione pustoszeją. Konfeszionałów starych $\mathrm{N}^{\text {ro }} 3$. Ołtarze wszystkie staroświeckie prostym kształtem robione. Kaplica do koscioła przymurowana gątami, pokryta, w sklepieniu wielkie pokazują się rysy; w niey okien 4; fundacyi Kreczyków $w^{52}$; ale już jej [tj. fundacjiMT] małe bardzo znaki dają się widzieć; pod Tytułem Niepokalanego Poczęcia; podczas wizyty ostatniej przeniesiony Obraz Immaculata i przyłączony do ołtarza Pocieszenia Matki Boskiej, a na miejsce przeniesionego obrazu mieści się obraz Miłosiernego Pana Jezusa. W tej kaplicy jest chrzcielnica ad piscina ${ }^{53} \mathrm{z}$ jednej,

${ }^{45}$ De Reliquiis (łac.) - Odnośnie relikwii.

${ }^{46}$ De Confraternitatibus et Indulgentiis (łac.) - Odnośnie bractw i odpustów.

${ }^{47}$ De Fabrica Ecclesiae (łac.) - Odnośnie budynków kościelnych.

${ }^{48}$ Opisywany kościół został rozebrany ok. 1916 r. Zachowały się jego zdjęcia jak wyglądała owa budowla na początku XX wieku, por. „Dawno temu w Czeladzi...” Wystawa fotografii wedtug koncepcji artystycznej Jerzego Żymirskiego, Czeladź 2002, s. I, 5, 12; T. Kostro, Zaglębie którego nie ma. Będzin-Czeladź-Dąbrowa-Sosnowiec, Łódź 2017, s. 53.

${ }^{49}$ Podsiebitka - sufit, strop.

${ }^{50}$ Tarcica - deska drewniana powstała w wyniku odcięcia jej od okrągłej kłody drewna; może mieć różną formę, np. deski, bala, belki, listwy, łaty.

${ }^{51}$ Sparsim (łac.) - w różnych miejscach.

${ }^{52}$ Por. Z. Jedynak, J. Drabina, Stosunki wyznaniowe, w: Historia Czeladzi, t. 1, s. 237-238; J. Wiśniewski, Diecezja częstochowska. Opis historyczny kościołów i zabytków w dekanatach: będzińskim, dąbrowskim, saczowskim, zawierckim i żareckim oraz parafii Olsztyn, Marjówka Opoczyńska 1936, s. 75.

${ }^{53}$ Ad piscinam (łac.) - obok pisciny; terminem tym określano zarówno kamienną misę umieszczoną w niszy na ścianie, w której dokonywano obmycia rąk przed mszą św. oraz w jej trakcie, 
$\mathrm{z}$ drugiej strony Olea Sacra w szafce w murze zamknięte. Ambona w większym chórze od zachodu do ściany przykuta robotą prostą z obrazem ś. Franciszka Xawerego. Tęcza drewniana $\mathrm{z}$ wyrażeniem Ukrzyżowanego. Chór muzyczny przy drzwiach

wielkich murowany z sklepieniem i trzema oknami. w ktorym są organy o 12 głosach dobrze zreparowane. Grobów murowanych w kościele trzy, czwarty w kaplicy. Drzwi wielkie kościoła ku południowej stronie blachą żelazną całe pokryte, kratami żelaznemi obite, zaporą i dobrym zamknięciem obwarowane. Od wschodu Słońca kruchta murowana sklepiona, w której są drzwi mniejsze do kościoła blachą żelazną, pokryte, zamkiem i kłotką opatrzone. Zakrystia w mniejszym chórze ku zachodowi murowana, do muru kościelnego przyłączona, do niej drzwi blachą żelazną pokryte, zamknięciem dobrym opatrzone, wewnątrz sklepiona. Wyżej zakrysti jest skarbiec pod dobrym zamknięciem drewnianemi kratami obwarowany. W tejże są szafy, na apparaty, dobre drewniane, cała gątami pokryta, w ktorej są dwa dzwony, większy i mniejszy, jest także dzwonek za konających. Cmentarz murem obwiedziony w którym jest brama z kratą żelazną od miasta ku wschodowi; i trzy forty, od północy, zachodu z kratami, od południa z drzwiami bez kraty. Kosnicy nie ma, bo przed kilku lat było pochowanie kości. Teraz gdy się kopią doły na cmentarzu, razem z spuszczonym trupem, wydobyte kosci wrzucają się do dołu.

W tym kościele znaydują się napisy ${ }^{54}$. 1wszy przy zakrystyi:

Generosus Fridericus Paczek de Wroczymowice in Milejowice et Dąbrowka Haeres Tenutarius Będzinensis, florente aetate, In lustrandis dißitis Regionibus et Regnis transactâ, maturâ vero negotiis Serenißimi Regis et Sanctus Regni, Publicis, impensa Fide, qua sua in Patriam, hostes ejusdem, strenue profligando, et stata Magnorum, favorem maximum nactus, obdormivit in Domino Anno $[\ldots]^{55}$ Mense $[\ldots]^{56}$.

a także puryfikacji naczyń liturgicznych po zakończeniu mszy św., jak i otwór w posadzce (rodzaj studni), do którego wylewano np. zużytą wodę z chrzcielnicy czy wodę pozostałą po praniu tzw. bielizny liturgicznej. Opis chrzcielnicy w kościele w Czeladzi (por. przypis 12) wskazuje, że był to rodzaj studni, odprowadzającej wylewaną wodę prosto do gruntu.

${ }^{54}$ Powyżej cytowane epitafia i tablice zostały przed zburzeniem starego, opisywanego tutaj kościoła, przeniesione do nowej, neoromańskiej świątyni w Czeladzi. Nową świątynie poświęcono 13 marca 1912 r., zgodę zaś władz na rozbiórkę starego kościoła uzyskano 24 marca 1914 r. Stary kościół rozebrano według wszelkich danych w 1916 r. Opisując w okresie międzywojennym kościół parafialny św. Stanisława w Czeladzi, ks. J. Wiśniewski podał także teksty znajdujących się w tej świątyni epitafiów i tablic. Por. M. Trąba, Stosunki wyznaniowe, w: Historia Czeladzi, t. 1, Czeladź 2012, s. 504; Wiśniewski, Diecezja częstochowska, s. 78-80.

${ }^{55}$ Pozostawiono puste miejsce w tekście inskrypcji.

${ }^{56}$ Pozostawiono puste miejsce w tekście inskrypcji. Tłumaczenie: Szlachetny Fryderyk Paczek z Wroczymowic, dziedzic Milejowic i Dąbrówki, dzierżawca będziński. Będąc w sile wieku zajmował się zarządzaniem (przeglądem) posiadłości w okolicach, zaś w wieku dojrzałym wypełniał publiczne obowiązki powierzone mu przez Najjaśniejszego Króla i Senat Królestwa. Dzięki niezmiernemu poświęceniu dla ojczyzny i gorliwej walce z jej wrogami dostąpił wielkiej łaski i życzliwości. 
2gi Przy kaplicy:

\author{
D. O. M.
}

Sistte gradum Viator

Quis quis ades, qui morte cades, dices posteris.

$\mathrm{Si}$ virtutem aestimas, hic extinctam legis.

Dum mortalis ipse mortalitatis Typum inspicies

hic depositus jacet,

Magnificus Generosus Dominus Michael de Jaroszyn Jarocki

Rothmagister olim Nobilitatis Severienę et Ductor,

Cujus si virtutem aestimas

Ferreum quondam in morte Polono Militem

Tam Turcicas inter hostas

Quam Scithicas inter sarischas

et alia bellica tormenta

Vitam pro Patria ponere volentem.

Pulchram quaerentem, et non invenientem mortem

agnosces ides

Quia non cita morte, sed longeva, si possibilis esset

dignus pro meritis fuerat vita,

ergo amice Lector cave,

Ne hunc ferreum ante virum mortuum esse putes.

Vivit ille non jam ferreus sed aureus.

Quia in aurea pia, grataque tam dilectae suae Uxoris

Magnificae ac Generosae Dominae Evae de Trzebienia Trzebienska

Quam Consanguineorum vicinorum, amicorum, nobilium

Pauperum Subditorum, aureis literis

Ut diu splendeat exarata memoria

Si vivum amasti, ora pro amico

Si odisti, non invideas, parce sepulto. Mortuus Anno 1702.

Die 4ta Martij

aetatis sua Annor $55^{57}$.

Zmarł w Panu w roku.... w miesiącu .... (thum. B. Machowska-Jaros). W prezentowanym tekście nie odnotowano istnienia żadnego dopisku na lub w pobliżu inskrypcji nagrobnej. J. Wiśniewski podaje, że w chwili kiedy on opisywał kościół czeladzki, czyli w okresie międzywojennym, pod inskrypcją widniała dopisana data 1628; por. Wiśniewski, Diecezja częstochowska, s. 79.

${ }^{57}$ Bogu Najlepszemu Największemu//Zatrzymaj się, pielgrzymie//Kimkolwiek jesteś, śmiertelniku, powiesz to potomnym//Jeśli cenisz cnotę [męstwo], to wiedz, że ona tu zgasła//Gdy ty, jako śmiertelny, spojrzysz na obraz przemijania.//Tu leży złożony//Wspaniały i szlachetny Michał z Jaroszyna Jarocki//Rotmistrz i dowódca szlachty siewierskiej//Jeśli cenisz jego męstwo, to dowiesz się,//Że nie zawahał się oddać życia za ojczyznę//Jako żołnierz w wojnie,//pomiędzy tureckimi włóczniami i scytyjskimi mieczami,//wśród wielu machin wojennych.//Szukał pięknej śmierci, a nie znalazł jej.//Zasłużył na nagrodę nie z powodu szybkiej śmierci, lecz długiego życia.//Dlatego, zacny przyjacielu uważaj,//abyś nie sądził, że jest martwy ten,//który wcześniej był niezłomny (nie do pokonania)//On żyje już nie jako żołnierz, lecz już w pełni chwały//W znakomitej pamięci zarówno swej ukochanej żony,//wspaniałej i szlachetnej Ewy de Trzebienia Trzebieńskiej//Jak i bliskich krewnych, przyjaciół i poddanych sług.//Aby pamięć [o nim] wyryta złotymi zgłoskami przetrwała 


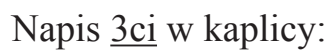

\author{
Jesus Maria Joseph \\ Acheu, labores vitae nostrae solvit mors; \\ Convictus humanos rumpit mors. \\ Tu dulcis Jesu salva nos, \\ Posteritas paribus indica, juva nos
}

Tibi Jesu vixi, Tibi morior, ut tuus sim aeternè praecor

1688. Andreas Kreczyk ${ }^{58}$.

4ty w tejże kaplicy:
Tere $\beta y$ Felicyanny ze Bzowa Kreczykowy pobozney
Małzonki lat 33 pracuiącey złozone ciało w Grobie,
tobie Czytelniku terminu smiertelnosci pewnemu,
pomoc Duszy zaleca załosny Małzonek. Obijt 4 Decembris
1685. aetatis annorum 46. Teresia Kreczykowa ${ }^{60}$.

\title{
Inwentarz sprzętów i ruchomości koscioła farnego w Czeladzi
}

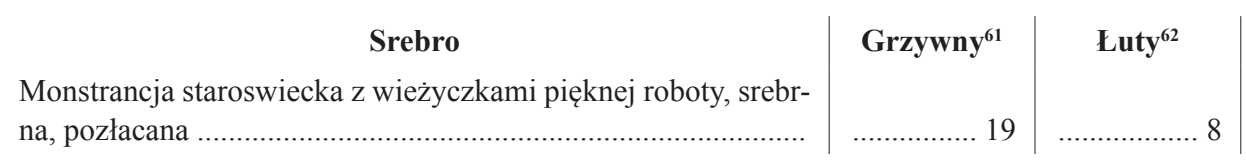

na wieki.//Jeśli kochałeś go za życia módl się za przyjaciela.//Jeśli zaś nienawidziłeś, zaniechaj, oszczędź zmarłemu. Zmarł w roku 1702 dnia 4 marca,//w wieku 55 lat. (tłum. B. Machowska-Jaros).

${ }^{58} \mathrm{~W}$ wypadku tego tekstu istnieją różnice pomiędzy zapisem w edytowanym dokumencie, a zapisem przytoczonym przez ks. J. Wiśniewskiego. Choć są to minimalne różnice przytaczamy tłumaczenie obu wersji zapisu. Wersja z rękopisu: Jesus Maria Joseph//Acheu, labores vitae nostrae solvit mors//Convictus humanos rumpit mors.//Tu dulcis Jesu salva nos,//Posteritas paribus indica, juva nos//Tibi Jesu vixi, Tibi morior, ut tuus sim aeterne precor. Tłumaczenie: Jezus Maria Józef.// Ach cóż! Od trudów uwalnia nas śmierć,//Śmierć zrywa ludzkie kajdany//Ty, słodki Jezu, ocal nas// Potomności, wesprzyj nas i poleć przyszłym pokoleniom//Jezu, dla Ciebie żyłem i dla Ciebie umieram. Proszę cię, abym należał do Ciebie na wieki (tłum. B. Machowska-Jaros). Wersja przytoczona przez ks. J. Wiśniewskiego: Jesus Maria Joseph//Echeu, labores vitae nostrae solvit mors//convictus humanos rumpit mors.//In dulcis Jesu salva nos,/Posteritas panibus inclina juva nos//Tibi Jesu vixi, Tibi morior, ut tuus sim aeterne precor. Tłumaczenie: Jezus Maria Józef.//Ach cóż! Od trudów uwalnia nas śmierć,//Śmierć zrywa ludzkie kajdany//Ty, słodki Jezus ocal nas//Potomności, nachyl się ku nam i wesprzyj nas pokarmem duchowym//Jezu, dla Ciebie żyłem i dla Ciebie umieram. Proszę cię, abym należał do Ciebie na wieki (tłum. B. Machowska-Jaros).

${ }^{59}$ DOM - (łac.) Deo Optimo Maximo, Bogu Najlepszemu Największemu.

${ }^{60}$ Obijt 4 Decembris 1685. aetatis ann[?] 46. Teresia Kreczykowa (łac.) - Zmarła 4 grudnia 1685 r. w wieku 46 lat Teresa Kreczykowa.

${ }^{61}$ Grzywna - 1) dawna jednostka miary masy stosowana głównie do określania wagi monet oraz wagi probierczej srebra; 2) dawna jednostka monetarna.

${ }^{62}$ Łut - dawna jednostka miar masy; 1 tut $=1 / 16$ grzywny. 
Monstrancya druga mniejsza do Kaplicy Niepokal[anego] Poczęc[zęcia] M[aryi] P.[anny]

Monstrancyka trzecia do ś. Anny .....

Kielich duży pięknej roboty z pateną pozłacany

Kielichów innych pozłacanych z patenami $\mathrm{N}^{\mathrm{ro}} 5$

Puszka pozłacana w cyborium

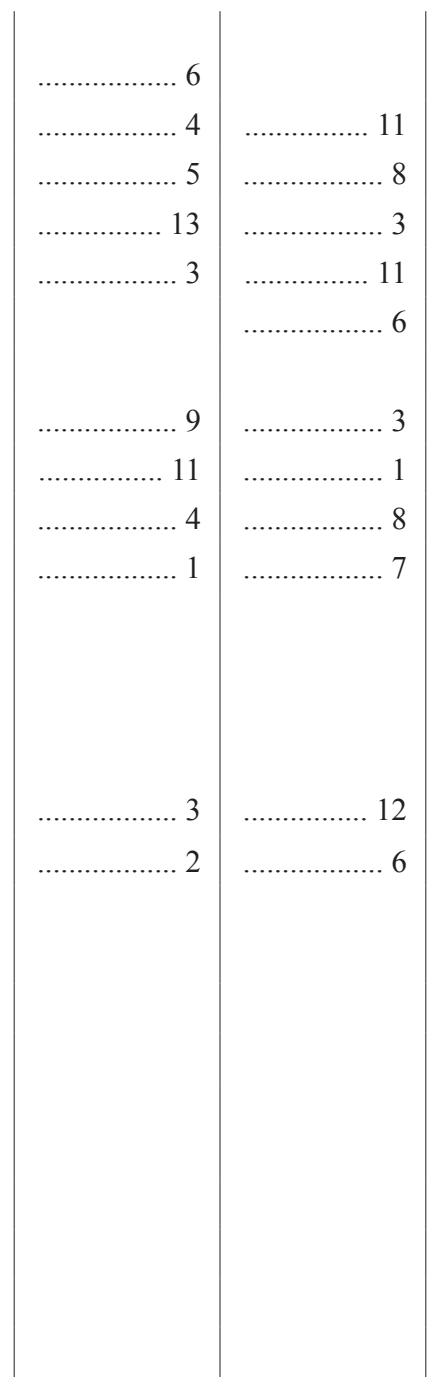

Vasculum wewnatrz wyzłacane do chorych

Vasculum na Olej Święty do chorych złe, nieważone

Trybularz $^{63} \mathrm{z}$ łotką ${ }^{64}$ i łyżeczką

Lampa duża srebrna

Krzyz procesionalny

Ampułek srebrnych para jedna

Wotow srebrnych do Niepokalanego Poczęcia $\mathrm{N}^{\text {ro }} 2$.

Korona gięta $\mathrm{N}^{\text {ro }} 1$. Łancuszek podwoj[ny] pozłac[any] $\mathrm{N}^{\text {ro }}$ 1. Wotów do Najsw[iętszej] M[aryi] P[anny] Pociesze[nia] $i$ ś. Anny $\mathrm{N}^{\text {ro }} 13$. Talerow bitych z uszkami $\mathrm{N}^{\text {ro }} 2$. Metalikow $\mathrm{N}^{\text {ro }}$ 3.Krzyżyk $\mathrm{N}^{\text {ro }} 1$. Koron $\mathrm{N}^{\text {ro }} 2$. Koronek małych $\mathrm{N}^{\text {ro }} 2$. to wszystko wazy

Lampa w serce robiona

Perly i korale

Pereł do Najśw[iętszej] Marij Panny Pocieszenia nici

Korali z różnych obrazów nici $\mathrm{N}^{\text {ro }} 40$

\section{Miedz, Mosiądz, Cyna, Żelazo}

Kociołek Chrzcielnicy miedziany pobielany nowy ... $\mathrm{N}^{\mathrm{ro}} 1$.

Kociołek na wodę swięconą . No 1 .

Kotłow do bębnienia . $\mathrm{N}^{\text {ro }} 2$.

Kociołek na wodę swięconą stary Nro 1 .

Krupka na hostye

Miednica mosiężna 1

Lustrów 3

${ }^{63}$ Trybularz - kadzielnica, przyrząd używany w czasie liturgii, w którego wnętrzu rozpalano ogień służący do obkadzeń w trakcie sprawowania liturgii; najczęściej w formie metalowego koszyka zawieszonego na trzech łańcuszkach

${ }^{64}$ Łódka - naczynie, w którym przechowywano kadzidło, np. suszone zioła i zasuszoną żywicę, przenoszone za pomocą łyżeczki do trybularza i używane do spalania podczas okadzeń w trakcie sprawowania liturgii. 


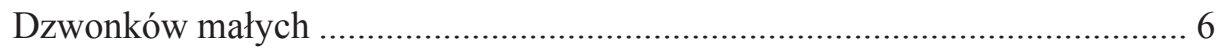

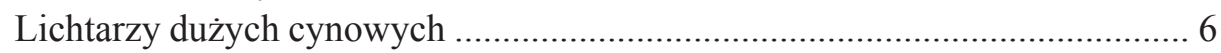

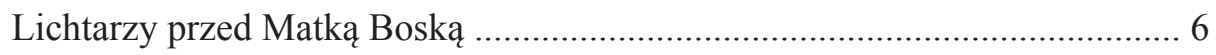

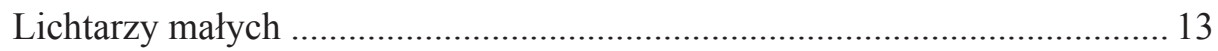

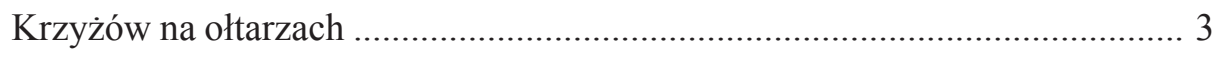

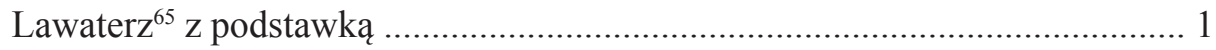

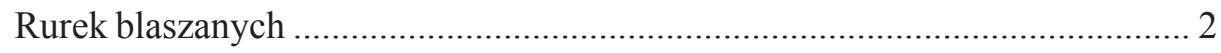

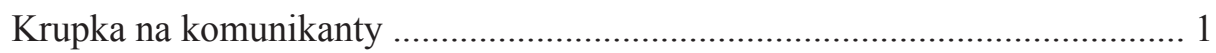

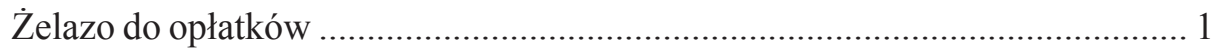

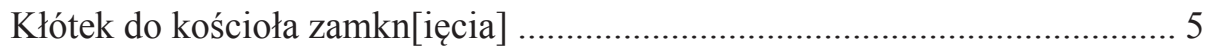

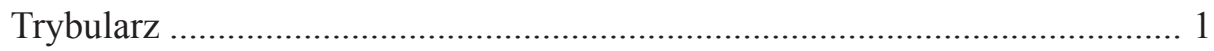

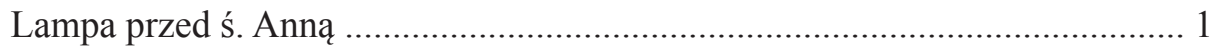

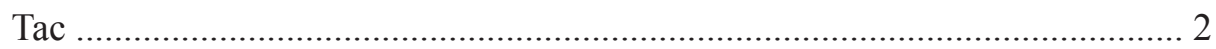

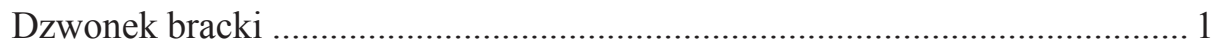

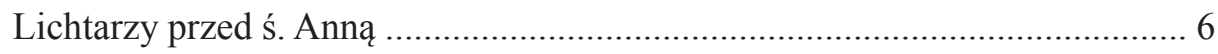

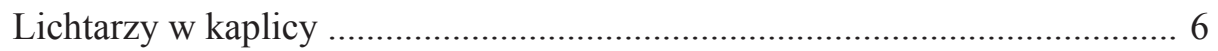

Krzyż wielki. 1 Pacyfikał mosię[żny] ......................................................... 1

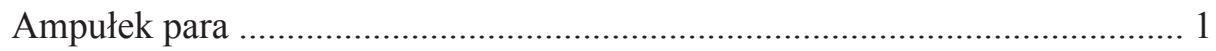

Łódka cynowa z łyżeczką ................................................................. 1

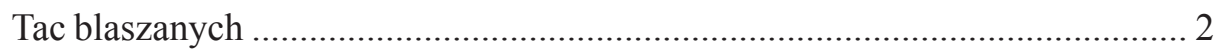

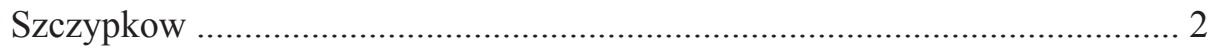

Cyrkuł ${ }^{66}$ do komunikantow ….............................................................. 1

Pieczęć żelazna kościelna ................................................................. 1

${ }^{65}$ Lawaterz - naczynie używane w czasie mszy św. do obmywania rąk przez kapłana podczas ofiarowania.

${ }^{66}$ Cyrkuł do komunikantów - przyrząd służący do wycinania okrągłych komunikantów lub hostii; metalowe koło z zaostrzonymi krawędziami i rączką. 


\section{Apparaty. Ornaty Białe.}

1. Francuskiej materyi w kwiaty srebrne, i jedwabne, galonem ${ }^{67}$ białym szychowym $^{68}$ oblamowany z stołą ${ }^{1}$ i manipularzem ${ }^{69}$.

2. W kwiaty złote, i srebrne i jedwabne różnego koloru, galonem złotym oblamowany, kitajką ${ }^{70}$ niebieską podbity z stołą, manipularzem.

3. Na dnie białym w kwiaty złote, srebrne i jedwabne różnego koloru kompanką ${ }^{71}$ szychową oblamowany, z stołą, manipularzem.

4. W kwiaty jedwabne różnego koloru cały jednaki, galonem szychowem żółtym oblamowany z stołą, manipularzem.

5. Tejże materyi z kolumną szychową białą, w kwiaty jedwabne szytą, galonem szychowem oblamowany, z stołą, manipularzem.

6. W kwiaty jedwabne różnego koloru, galonkiem szychowem żółtym oblamowany, z stołą i manipularzem.

7. W kwiaty różnego koloru jedwabne, taśmą jedwabną oblamowany, z stołą i manipularzem.

8. Takiejże materyi z stołą manipularzem.

9. Materyi staroświeckiej, taśmą modrą jedwabną oblamowany z stołą i manipularzem.

10. Połatłasowy z kolumną partyrową ${ }^{72}$, taśmą białą jedwabną oblamowany, z stołą i manipularzem.

11. Adamaszkowy z kolumną atłasową, czerwoną, i taśmą jedwabną żółtą oblamowany z stołą y manipularzem.

\section{Ornatów starych nędzowych ${ }^{73} \mathrm{z}$ należytosciami $\mathrm{N}^{\mathrm{ro}} 2$.}

${ }^{67}$ Galon - taśma tkana lub pleciona wykonana w całości lub w części z metalowych nitek, najczęściej naszywana na ubrania w celu ich ozdoby; wykorzystywana często dla oznaczenia stopni wojskowych. Zajmujący się wyposażeniem kościołów w Polsce ks. A. Brykczyński pisał w XIX wieku: „Dla podniesienia piękności [aparatów kościelnych - MT] używa się galonów, które powinny być złote lub jedwabne, bo wszelkie szychy są nader nietrwałe, prędko czernieją i wyglądają bardzo ordynarnie. We Włoszech nie używają wcale galonów białych, ale u nas takowe są rozpowszechnione, a że są przystępniejsze co do ceny i nader efektowne, a nigdzie nie zakazane, przeto je bardzo zalecam, ale rozumie się prawdziwie srebrne lub jedwabne”, por. A. Brykczyński, Dom Boży to jest praktyczne wskazówki budowania, naprawiania i utrzymywania kościołów na wzór dzieła X. Montault „Traité prtique de la construction, de l'ameublement et de la décoration des églises”, Warszawa 1888, s. 239.

${ }^{68}$ Szych - nić owinięta cienkim drucikiem, używana do haftu, przy ozdabianiu ubiorów oraz do wyrobu tkaniny szychowej.

${ }^{69}$ Manipularz - szata liturgiczna w postaci wstęgi materiału (małej stuły) noszona przez kapłana podczas sprawowania mszy św. na lewej ręce; od czasu reform Soboru Watykańskiego II nie jest wykorzystywana podczas liturgii.

${ }^{70}$ Kitajka - rodzaj tkaniny jedwabnej; źródłem nazwy tkaniny jest rosyjska nazwa Chin - Kitaj; był to najtańszy, najprostszy i najbardziej popularny rodzaj tkaniny jedwabnej rozpowszechniony w Rzeczypospolitej.

${ }^{71}$ Kompanka - wąska koronka, wyrabiana w Polsce od XVII wieku; służyła przede wszystkim do poszerzania droższych koronek brukselskich.

${ }^{72}$ Tkanina partyrowa - wyrób jedwabny o kwiatowym wzorze.

${ }^{73} \mathrm{Nędza}$ - tkanina jedwabna lub półjedwabna gorszego gatunku. 
13. Po wizycie przybył ornat biały z kwiatami złotemi i srebrnemi na białym dnie, galonem złotym oblamowany z stołą, manipularzem.

14. Ornat żółtawy białemu służący z kolumną czerwoną, taśmą złotą oblamowany z stołą i manipularzem.

\section{Ornaty czerwone}

1. Aksamitny z kolumną białą w kwiaty złote, i jedwabne, galonem szychowym białym żółtym oblamowany, z stołą i manipularzem dobieranemi.

2. Ponsowy, w kwiaty białe, galonem białym szychowym oblamowany z stołą, manipularzem.

3. Materyi francuskiej w kwiaty różne, galonem białym szychowym oblamowany, z stołą, manipularzem.

4. Adamaszkowy tasiemką żółtą jedwabną oblamowany z stołą i manipularzem.

5. Staroswieckiej materyi w kwiaty złote, koronką szychową żółtą oblamowany, z stołą, manipularzem.

[s. 254]

6. Adamaszkowy z kolumną niebieską galonem żółtym szychowym oblamowany, $\mathrm{z}$ stołą, manipularzem.

7. Takiż, galonem takimże oblamowany z stołą manipularzem.

8. Adamaszkowy taśmą niebieską oblamowany z stołą, manipularzem.

9. Adamaszkowy z kolumną białą tasiemką zieloną oblamowany z stołą i manipularzem.

10. Nędzowy cały spłowiały, galonem szychowym białym oblamowany z stołą, manipularzem.

11. Spłowiały z kolumną niebieską galonem białym szychowym oblamowany $\mathrm{z}$ stołą, manipularzem.

12. Spłowiały z kolumną w kwiaty, tasiemką modrą oblamowany, z stołą, manipularzem.

13. Spłowiały tasiemką szychową oblamowany, z stołą, manipularzem.

Stoła czerwona aksamitna, staroświecka, szychem przerabiana.

Ornaty zielone

1. Adamaszkowy z kolumną czerwoną tasiemką jedwabną oblamowany, z stołą, manipularzem.

2. Atłasowy z kolumną czerwoną tasiemką żółtą oblamowany, z stołą i manipularzem.

3. Nędzowy z kolumną żółtą nędzową, tasiemką białą oblamowany, z stołą, manipularzem.

\section{Ornaty fioletowe}

1. Aksamitu strzyżonego z kolumną czerwoną adamaszkową, galonem szychowym białym oblamowany, z należytościami dobieranemi.

2. W kwiaty szychowe białe i jedwabne różnego koloru, galonem szychowym żółtym oblamowany z stołą, manipularzem. 
3. Adamaszkowy z kolumną spłowiałą, czerwoną galonem białym szychowym oblamowany.

4. Adamaszkowy, tasiemką jedwabną białą oblamowany z stołą i manipularzem.

5. Nędzowy stary tasiemką oblamowany bez stoły i manipularza.

\section{Ornaty czarne}

1. Parterowy z kolumną nędzową żółtą, kompanką szychową białą, oblamowany $\mathrm{z}$ stołą i manipularzem.

2. Aksamitny z kolumną białą w kwiaty srebrne i jedwabne galonem szychowym żółtym oblamowany z stołą, manipularzem.

3. Rojowy ${ }^{74} \mathrm{z}$ kolumną białą $\mathrm{w}$ kwiaty żółte jedwabne galonym szychowym żółtym oblamowany z stołą, manipularzem.

4. Adamaszkowy z kolumną białą w kwiaty jedwabne różnego koloru, galonem białym szychowym oblamowany z stołą, manipularzem.

5. Atłasowy z kolumną białą $\mathrm{w}$ kwiaty szychowe białe i jedwabne kompanką białą szychową oblamowany z stołą i manipularzem.

6. Adamaszkowy z kolumną szychową w kwiaty różnego koloru, galonym szychowym żółtym oblamowany z stołą, manipularzem.

Ornatów do kaplicy należących jest starych 5: biały, czerwony, zielony, fioletowi i czarny. Z stołami i manipularzami.

Po wizycie przybyły dwa czarne ornaty: 1. z materyi rzymskiej, 2. z piękniejszego i cieńszego kamlotu ${ }^{75}$ białym szychem oblamowane z przynażyłościami.

[s. 255]

Kapy

1. Bogata, na dnie lito srebrnym z kwiatami dużemi złotemi i jedwabnemi, koronkami złotemi obwiedziona, i złotemi franslami w tyle przyozdobiona, z klamerkami srebrnemi, kitajką karmazynową podbita, z stołą bogatą tejże materyi.

2. Biała w kwiaty srebrne, i iedwabne różnego koloru galonym żółtym szychowym oblamowana.

3. Biała morowa ${ }^{76}$ stara, galonem żółtym szychowym oblamowana.

4. Czerwona adamaszkowa galonem białym szychowym oblamowana.

5. Zielona spłowiała, tasiemką jedwabną niebieską oblamowana.

6. Fioletowa aksamitna, tasiemką jedwabną białą oblamowana.

7. Czarna z listwą niebieską w kwiaty kompanką szychową białą oblamowana.

8. Po wizycie przybyła kapa aksamitna koronkami srebrnemi obwiedziona, i srebrnemi franslami w tyle przyozdobiona, z klamerkami srebrnemi, kitajką niebieską podbita z stołą tejże materyi.

\footnotetext{
${ }^{74}$ Roja - tkanina wełniana o kosmatej fakturze.

${ }^{75}$ Kamlot - cienka, rzadko tkana tkanina z szorstkiej wełny czesankowej gorszego gatunku, produkowana w Polsce od XIV do XVIII wieku.

${ }^{76}$ Mora - gładka, jednobarwna tkanina jedwabna lub półjedwabna, rzadziej bawełniana lub wełniana, poddana procesowi morowania, czyli maglowaniu żelaznym lub skórzanym walcem, w celu uzyskania nieregularnych smug.
} 
Przybyło także Tabernaculum białe, z kwiatami złotemi i srebrnemi na białym dnie, galonem złotem, i szychowym żółtym, oblamowane.

\section{Firanki, Antepedia i Sprzęty różne}

Firanek czerwonych parterowych z oblamką kitejkową para 1

Kitejkowych niebieskich z oblamką czerwoną jedwabną para ........................... 1

Partyrowych z oblamką szychową połtory sztuki.

Żółtych kitejkowych szychem obwiedzionych para

Żółtych rojowych z oblamką szychową białą para

Kitejkowych czerwonych spłowiałych szychem żółtem obwiedzio: para ............ 1

Parterowych zielonych z oblamką kitejkową czerwoną para ................................ 1

Kitejkowych białych w prązki różnego koloru para ............................................. 1

Kitejkowych żółtych z oblamką niebieską para .................................................... 1

Siatkowych płótnem czerwonym podszytych para ……...................................... 1

Kitejkowych białych szychem obwiedzionych para ........................................... 1

Atłasowych w czerwone i białe prązki para ...................................................... 1

Żółtych atłasowych z cętkami białemi, z niebieską stąszką z 5 kutas[ami] złote[-

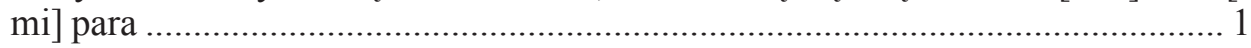

Niebieskich, gredyturowych ${ }^{77} \mathrm{z}$ szychem białym para .................................. 1

Niebieskich kitejkowych z szychem białym para ................................................ 1

Kitejkowych czerwonych zpełzłych para ……................................................. 1

Kitejkowych zielonych z szychem żółtem para ................................................... 1

Kitejkowych mienionych z szychem białym para ............................................. 1

Ataminowych ${ }^{78}$ w prążki z oblamką kitejkową para ............................................ 1

Chustek jedwabnych starych złotem wyszywanych ........................................... 2

Po wizycie przybyły duże firanki białe z kwiatami złotemi i srebrnemi na białym dnie taśmą żółtą oblamowane u Miłosiernego Pana Jezusa.

Przybyło feretrum ${ }^{79}$ nowe wyzłacane. Mszał nowy.

Antepedyó $^{80} \mathrm{w}$ różnych kolorach i materyi .................................................. 3

Baldachin nowy o czterech laskach .................................................................. 1

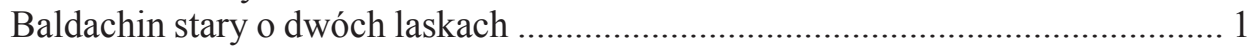

Biretow 5.

Pasek jedwabny 1 .

Pasków włóczkowych 2. Niciany 1.

$\operatorname{Sup}[\ldots]^{81} 3$.

Oppon na zasłonienie ołtarzy 3.

Oppona szkotowa 1. haftów.

${ }^{77}$ Gredytur (grodetur) - gęsta tkanina jedwabna, średniej grubości, wykorzystywana często do

${ }^{78}$ Atamin (etamina) - lekka, przejrzysta tkanina jedwabna, tkana splotem płóciennym.

${ }^{79}$ Feretrum (łac. feretrum, -i) - katafalk, mary, całun.

${ }^{80}$ Antependium (łac. antependium, -ii) - zasłona na przednią część ołtarza, najczęściej w postaci tkaniny rozpiętej na drewnianej ramie, rzadziej drewniane bądź skórzane; często bogato zdobione $\mathrm{i}$ haftowane; kolor zakładanego antependium zależał od okresu roku liturgicznego.

${ }^{81}$ Słowo nieczytelne. 
Zasłon do zasłonienia S[ancti]S[i]mi 3.

Poduszek pod mszały 4.

Chorągwi wielkich starych 4. małych 4.

Proporcow 4.

Proporców z laterniami 2.

Obrazów brackich do noszenia 3.

Lasek brackich ${ }^{82} 3$.

Passya Wielka Bracka 1.

Passyi pomniejszych 2.

Statua Zmartwychwstania Pańskiego 1.

Krzyżów drewnianych 2.

Kap brackich 20.

Giermaków $^{83}$ sukiennych 3.

Lichtarzy drewnianych większych par 3. mniejszych par 3.

Katafalk z trumną i mary.

Krzesło skórą obite 1.

Pacyfykał półmosiężny półdrewniany 1 .

Worek z dzwonkiem 1.

Szafa na choragwie 1 .

Kobierców tureckich 4.

Przybyło szczypców 2.

Bielizna

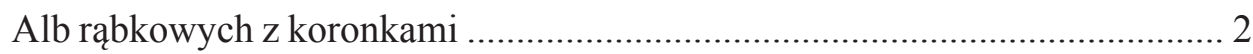

Alb nowych z koronkami ................................................................... 4

Alb cienkich grubsz[ych] naprawnych .............................................. 7

Humerałów ${ }^{84}$ cieńkich, grubszych ...................................................... 12

Puryfikaterzów ${ }^{85}$........................................................................................... 50

Tuwalnia $^{86}$ rąbko[wana] z koron[kami] białemi ........................................... 1

Tuwalnia cień[ka] jedwab[na] szych[owan] wyszy[ywana] ......................... 1

Tuwalni rąbkow[ana] wyszywa[ana] białym ................................................. 3

Obrusów z wyszyw[aniem] białym, czerw[onym] ...................................... 13

Połobrusow z wyszyw[aniem] czerw[onym], białym ............................ 11

${ }^{82}$ Laski brackie - rodzaj prostej laski drewnianej, zakończonej metalowym okuciem; symbol władzy osób dbających o porządek w kościołach; często funkcję ową powierzano członkom istniejącego przy kościele bractwa.

${ }^{83}$ Giermak - rodzaj wierzchniego ubrania w postaci długiej, luźnej sukni.

${ }^{84}$ Humerał - (łac. humerale, -is) szata liturgiczna koloru białego, najczęściej w postaci prostokątnego kawałka materiału z dwoma, długimi tasiemkami; celem zakładania humerału było osłonięcie szyi oraz ramion, gdy nie czyniła tego alba.

${ }^{85}$ Puryfikaterz - (łac. purificatorium, -ii) kawałek płótna używany do oczyszczenia (puryfikacji) kielicha lub puszki.

${ }^{86}$ Tuwalnia - szeroki pas ozdobnej tkaniny zakładany na ramiona przez osoby duchowne; używany w czasie procesji, błogosławieństwa Najświętszym Sakramentem i przenoszenia tegoż; przez ten materiał osoba duchowna dotyka np. monstrancji czy puszki z Najświętszym Sakramentem. 


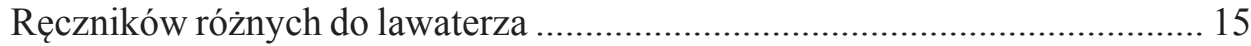

Chustek płociennych wyszyw[anych] ................................................... 3

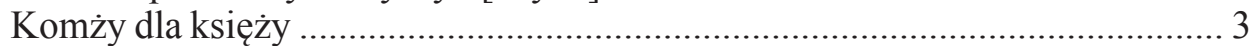

Alb cienkich z koronką kitajką pons[owych] podbit[ych] ............................. 2

Alb cienk[ich] i grubszych dobrych z koronka[mi] .................................... 7

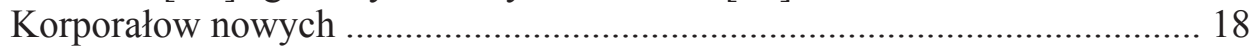

Tuwalnia złotem i jedwabiem batysto[wa] wyszy[wana] .............................. 1

Tuwalnia rąbkow[ana] cien.[?] grubszych wyszyw[ana] ................................ 14

Obroz płocienny nowy z koron[ką] ......................................................... 1

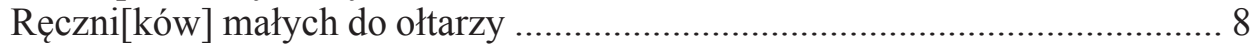

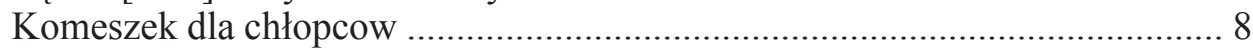

Summariusz różnych fundacyi do ołtarzów

Fundacje do prebendy czyli ołtarza Pocieszenia Najś[więtszej] M[aryi] P[anny]

1691. W poniedziałek po Niedzieli Laetare ${ }^{87} \mathrm{w}$ grodzie siewierskim złp $\underline{3000}$ na dobrach Pogoni w księstwie siewierskim. Zapis.

1681. We wtorek po Niedzieli kwietnej88 w tymże grodzie złp 2000 na dobrach Chroszczobrod w tymże księstwie. Zapis.

1646. We wtorek przed ś[wię]tym ś. Małgorzaty Panny i Męczen[nicy] w grodzie krakow[skim] złp 1000 na dobrach Kąpiołki w województwie krak[owskim] w powiecie lelowskim. Zapis.

1765. Dnia 11 października przed urzędem radzeckim będzińskim, złp $\underline{700}$ na synagodze w Będziniu w województwie krakowskim. Zapis.

1782. Dnia 12 marca, przed tymże urzędem w Będziniu f. pol. 124 na synagodze będzimskiej. Zapis.

1783. Dnia 22 lipca przed tymże urzędem złp $\underline{500}$ na tejże synagodze będzińskiej. Zapis.

1773. Dnia 30 lipca przed tymże urzędem złp 216 na roli w Będziniu Sław[etnego] Styrkowskiego. Zapis.

1780. Dnia 15 kwietnia przed tym ze urzędem złp $\underline{100}$ na Łąkach w Będziniu Sław[etnego] Solnickiego. Zapis.

1777. Dnia 6 maja przed wspomnianym urzędem złp $\underline{100}$ na całym mieście Będziniu. Zapis.

Przed aktami radzieckiemi czeladzkiemi f. pol. 1173 na rolach, domostwach, stodołach Sławett[nych] Obywatelów w Czeladzi w księstwie siewierskim. Zapisy.

Fundacje do kapelanii czyli ołtarza Niepoka[lanego] Poczęc[ia] M[aryi] P[anny]

$\mathrm{Na}$ Dobrach Łagiewniki w Ślasku prywatny zapis f. pol. ${\underline{500^{\#}}}^{\#}$.

[dopisek na dole strony:

${ }^{87}$ Niedziela Laetare - nazwa IV niedzieli Wielkiego Postu; nazwa wywodzi się od pierwszych słów antyfony na wejście (introitu) formularza mszy św. odprawianej w ów dzień: Laetare, Ierusalem (Wesel się, Jeruzalem,).

${ }^{88}$ Niedziela Kwietna - używana w Polsce nazwa Niedzieli Palmowej. 
\# Ta summa ma początek z umowy następującej. Ś. p. WJm ks. Michał Maurycy Komecki kustosz krak[owski], a pleban czeladz[ki] ugodziwszy się z kapelanem względem dziesięciny na Przełayce z wyższych wzorów dworskich od Kreczyka dziedzica fundowanej, czyli nadanej do kapelanii Immaculata Concept[io] B[eatae] M[ariae] V[irginis], za tę dziesięcinę zapłacił f. pol. 500 i bierze się prowizja corocznie f. pol. 30. Ta kompozycja ma być aprobow[ana] od biskupa.].

$\mathrm{Na} 10$ siągach $^{89}$ drzewa z erekcyi Kreczykow ktora już upada ${ }^{90}$. 1686. Dnia 3 pazdziernika. Przed aktami ziemskiemi bytomskiemi w Śląsku, złp $\underline{1000}$ na dobrach Przełayka. Zapis. Już upadło.

1692. Dnia 28 listopada. Przed aktami radzieckiemi krakowskiemi złp $\underline{500}$ na kamienicy, w Krakowie, między Kamienicą Dzibonicha ${ }^{91} \mathrm{z}$ jednej, a kamienicą pod Pawiem $^{92} \mathrm{z}$ drugiej strony, stoiącej, na ulicy ś. Jana ${ }^{93}$.Zapis. Już upadło.

Z kapitału 2000 płacił prowizyą f. pol. 120 Jm Pan Lazar Henkiel ${ }^{94}$ Graff Bytomski przez lat 14 . Brat jego rodzony starszy $y^{95}$ przez lat 16 . Ojciec ${ }^{96}$ przez lat 18 . Gdy potym wymagał na mnie Graff Lazar, aby mu pokazać ius petitorium ${ }^{97}$ wypłacenia tej prowizyi, ja po

[s. 257]

wielu szukaniach w różnych kancellaryach, tak w Ślasku jako i polskich, nie mogłem tego pokazać. Prowizja od 5 lat już upadła. a tak i fundacja Kreczyków iskierka tylko zostaje.

1686. Dnia 12 czerwca. Przed aktami radzieckiemi krakowskiemi złp 500 na ogrodzie na Czarnej Wsi zapis. Już upadło.

1777. Dnia 16 kwietnia. Przed urzędem tadzieckim będzińskim złp 100 na roli w Będziniu Sławet[nego] Kapuścika. Zapis.

1782. Dnia 12 marca. Przed tymże urzędem złp 50 na synagodze będzińskiej. Zapis.

${ }^{89}$ Siąg (starop.) - inaczej sąg, sześcienna miara drewna.

${ }^{90}$ Tekst dokumentu fundacyjnego patrz: J. Wiśniewski, Diecezja częstochowska, s. 75-76.

${ }^{91}$ Kamienica Dzibonich - obecnie kamienica przy ul. Św. Jana 26 w Krakowie; nazwa pochodzi od nazwiska właściciela budynku, którym był Włoch Baltazar Gibboni.

${ }^{92}$ Kamienica pod Pawiem - kamienica nosi nazwę Sub Pavone (Pod Pawiem) od XVII wieku; obecnie kamienica przy ul. Św. Jana 30 w Krakowie.

${ }^{93}$ Zapis dotyczył obecnego budynku przy ul. Św. Jana 28, tzw. Domu Piotrkowskiego; por. A. Chmiel, Domy krakowskie. Ulica św. Jana, Kraków 1924, s. 260-262.

${ }^{94}$ Łazarz III Henckel von Donnersmarck (1729-1805) - por. przypis 44.

${ }^{95}$ Franciszek Ludwik Henckel von Donnersmarck (1721-1768) - pan na Bytomiu w latach 1745-1768; w 1747 roku odzyskał skonfiskowane przez władze pruskie dobra rodzinne; rezydował w majątku Carlshof (Karłuszowiec) pod Tarnowskimi Górami, por. Kuzio-Podrucki, Henckel von Donnersmarckowie, s. 61-63, 94.

${ }^{96}$ Karol-Józef-Erdmann Henckel von Donnersmarck (1688-1760) - drugi wolny pan stanowy i pan Bytomia w latach 1699-1745; jego żona Maria Józefa w 1718 roku zakupiła dobra Bańgów i Siemianowice; w 1724 roku Karol Józef Erdmann do swych dóbr dołączył poprzez kupno dobra Przełajka; po II wojnie śląskiej, w której poparł Austrię musiał udać się na wygnanie do Wiednia i na Węgry, gdzie ostatecznie zmarł, por. tamże, s. 53-61.

${ }^{97}$ Ius petitorium (łac.) - tytuł własności; prawo sądowego dochodzenia własności; możliwość wniesienia actio petitoria, czyli skargi cywilnej w sprawie o prawo własności. 
1720. Dnia 16 grudnia. Przed aktami radzieckiemi czeladzkiemi złp 100 na roli w Czeladzi Sław[etnego] Kuczewicza. Zapis.

1736. Dnia 6 października. Przed temysz aktami czeladzkiemi złp $\underline{100}$ na roli Sławet[nego] Dworaczka w Czeladzi. Zapis.

1776. Dnia 15 maja Przed temysz aktami czeladzkiemi złp $\underline{100}$ na roli Koskały w Czeladzi. Zapis.

1776. Dnia 30 kwietnia. Przed temysz aktami złp 150 na roli Sławet[nych] Twardziszewskiego i Wojnaczyka. Zapis.

Fundacje do ołtarza Ś. Anny.

1725. We wtorek przed świętym ś. Piotra w Okowach w grodzie siewierskim złp 1000 na dobrach milejowice w tymże Księstwie. Zapis.

1782. Dnia 17 grudnia. Przed urzędem radzieckim będzińskim złp 100 na synagodze w Będziniu. Zapis.

1783. Dnia 10 grudnia. Przed tymże urzędem będzińskim złp 100 na wspomnionej synagodze. Zapis.

Przed aktami radzieckiemi czeladzkiemi złp 1568 na rolach, domach, stodołach Sławet[nych] Obywatelów. Zapisy.

Fundacja do ś. Jana Nepomucena

1769. Dnia 20 marca przed Aktami Grodzkiemi Siewierskiemi f. pol. 1000 na dobrach Zagorze w wojewodztwie krak[owskim] leżących. Zapis.

De Aedibus Parochialibus et aliorum ${ }^{98}$

Pomieszkanie plebańskie blisko kościoła murowane, z przysionkiem, gontami pobite. Wchodząc do sieni sklepionej wprost iest izba sklepiona $\mathrm{z}$ dwiema oknami, z kominkiem i piecem, z izby są drzwi do spiżarni sklepionej o jednym oknie. $\mathrm{W}$ tejże sieni drzwi do kuchni sklepionej z iednym oknem, jest także piwnica sklepiona. Idąc po wschodach na piętro jest salka mała z oknem na wschód Słońca, z ktorej salki są drzwi do pokoju pierwszego z dwiema oknami, piec i komin; $\mathrm{z}$ tego pokoju drzwi do drugiego pokoju, w ktorym okno jedno i kominek, $\mathrm{z}$ tego drzwi do trzeciego pokoju o jednym oknie; te pokoje są z zamkami. Z sali są wschody na górę pod dach, gdzie zrobione przegrody 4 na sypanie różnych zbóż. Przy tej plebani jest sad murem trochę nadpustoszałym kamiennym obwiedziony, którym znajdują się różnego gatunku drzewa rodzajnego, ale po większej częsci spruchniałe, i mało co pożytku przynoszące.

Do plebanii et kamieniczka przymurowana, gontami pokryta, należą plebanowi ${ }^{\mathrm{h}}$. Wchodząc do sieni są drzwi do izby o jednym oknie z piecem, kominkiem spustoszałym i drzwiami do komnatki z jednym oknem, piecem i kominkiem spustoszałym. Na przeciw jest stajnia obszerna dla koni, przy ktorej z iednej strony jest schowanie, ale spustoszałe, z drugiej strony wozownica dobra z wrotami na kunach żelaznych. Wieżdżając do plebanii szczupłym podworzem w bramę, w niej

\footnotetext{
${ }^{98}$ De Aedibus Parochialibus et aliorum (łac.) - Odnośnie domów parafialnych i innych [budynków].
} 
są wrota dobre pod zamknięciem. $Z$ plebanii idąc do koscioła jest fortka nowa $\mathrm{z}$ zasufką żelazną. Na zachod są wrota nowe $\mathrm{z}$ fortką pod zamknięciem.

Folwark

Za rzeką Brynnicą na gruncie pól plebanskich, Poświętnie nazwanych, jest folwark, nowo wystawiony na południe ze wszystkiemi wygodami; od południa wchod do sieni, z ktorej dzrzwi do pokoju z trzema oknami, piecem; z pierwszego są drzwi do drugiego pokoju z jednym oknem, piecem i kominkiem; w tym pokoiu jest dwoie drzwi, pierwsze do komnaty o jednym oknie, drugie do sieni; to wszystko pod zamknięciem zamkami francuzkiemi; w ktorej są drzwi na połnoc z dobrym i tęgiem zamkiem, tak że jest i komin całkowicie wymurowany do ktorego wszystkie dymy wpadaią, z dwojga drzwi od południa i na połnoc. Podłoga pokojow, komnaty i sieni z tarcic. W tejże sieni są wschody pod zamknięciem na górę tarcicami zapierzoną dla osobnego schowania, także i drzwi do obszernej piekarni z dwiema oknami, kominkiem, z piecem chlebowym. Z piekarni drzwi do izby gospodarskiej z dwiema oknami, piecem i kominkiem. W izbie są drzwi do spiżarnie gospodarskiej pod zamknięciem o jednym oknie, z okiennicami do wszystkich okien. W spomnionej piekarni są trzecie drzwi do drugiej sieni, w którey wschody na górę gospodarską pod zamknięciem. Ta sien ma dwoje drzwi od południa i na połnoc z zaporami i mocnym zamknięciem.

Przy tym folwarku jest drugi nowy budynek, w ktorym od południa wchodząc do sieni są drzwi do izby z oknem jednym, piecem i kominkiem murowanym, z pierwszej izby są drzwi do drugiej, o jednym oknie z okiennicami i podłogami $\mathrm{z}$ tarcic. $\mathrm{Z}$ tej izby są drzwi do spiżarnie, w ktorej wschody na górę z zamknięciem. Pod temi dwiema izbami jest sklep cały wymurowany na potrzeby folwarcznej czeladzi. O ścianę jest nowa wozownia $\mathrm{z}$ wrotami pod dobrym zamknięciem. Obie te budownie są gontami pokryte nowemi, a przez X. Wawrzyńca Hechthausa plebana czeladzkiego w roku 1790 i 1791 nakładem jego nowo wyfundowane.

Stodoły dwie, jedna jest dobra, druga starsza, mało jeszcze reparacyi potrzebuje. Spichlerz pod snopkami dosyć wygodny.

Stajnie, chlewy, chlewiki z karmnikiem częścią z nowego, częścią z starego drzewa wystawione i poprawione przez dzisiejszego plebana.

\section{Pomieszkanie Ks. Prebendarza oraz i Wikariusza Koscioła Czeladzk[kiego]}

Dom nowy gontami pokryty. Wchodząc do sieni po prawej stronie izba umalowana $\mathrm{z}$ kominkiem, piecem kaflowym, z dwiema oknami i komnatką, o jednym oknie, z okiennicami i z podłogą z tarcic. Po drugiej stronie izba z kominkiem, piecem kamiennym $\mathrm{z}$ dwiema oknami, z komorą o jednym oknie; z sieni po schodach idzie się do piwnicy nowo wymurowaney. $Z$ tejże sieni drzwi do ogrodu ogrodzonego, zasiewa się jarzyną do którego są wrota. jest tak, że stajnia słomą pokryta dla koni, drzwi sztabą żelazną obwarowane. Przy niej chlewik. To całe pomieszkanie jest z dziedzińcem dobrze oparchanione $\mathrm{z}$ wrotami, fortką pod mocnym zamknięciem. 
Do prebendy jest Rola Mrowczowska nazwana za fundacjonalne pieniądze kupiona przez Ks. Kaspra Kuczewicza99, roku 1756.

\section{Pomieszkanie Ks. Wikarego}

Dom cały nienadpsuty, gontami pokryty z sieni idzie się do izby, w której piec kaflowy, kominek, dwa okna, komnatka o iednym oknie $z$ okiennicami i podłogą z tarcic. $\mathrm{Z}$ drugiej strony izba czeladna $\mathrm{z}$ piecem murowanym, kominkiem, o dwóch oknach. Komora o jednym oknie. Są dwie stajnie spustoszałe. Przy budowni ogród na jarzynę ogrodzony dobrze. To pomieszkanie z podworzem jest dobrze oparchanione.

Dom kapelana cały spustoszony i poprawy niegodzien.

Do kapelanii jest Rola Kapelańska nazwana między rolami czeladzkiemi kupiona od mieszczanina przez Kreczyka dla kapelana.

Ma plac na stodołę na przedmieściu, do młyna idąc po prawej stronie przy zagrodzie organisty.

Organista domu żadnego nie ma.

Szpital w ktorym z sieni są drzwi do izby z podłogą z tarcic, piec kaflowy, kominek, trzy okna. 4 ubogich z jałmużny żyjących niż z dochodów bardzo szczupłych. $Z$ drugiej strony izby iest i[z]debeczka z piecem, kominkiem i dwiema oknami, z kraczką o jednym oknie. Przed szpitalem Boża Męka drewniana na której ukrzyżowany Pan Jezus na blasze malowany. Przy szpitalu iest plac należący temuż ubóstwu.

\section{Podani plebańscy}

Ma pleban podanych 13. Sześciu mając pomieszkanie i 100 zagonów sześcioskibowych. Z pola plebańskiego udzielonych robią po dwa dni w tydzień. Siedmiu mając pomieszkanie i 50 zagonów z tegoż pola, robią po półtora dnia w tydzień, pieszo wszyscy. Ich domki niektóre potrzebują znacznej reparacyi.

De Dote Ecclesiae seu Reditibus ${ }^{100}$

Dwa dokumenta należytosc kościoła dowodzą.

1440. Liber Beneficiorum ${ }^{101}$.

${ }^{99}$ Ks. Kasper (Kacper) Kuczewicz - 1749-1756 pleban parafii Mokre (Mokra) w dekanacie pszczyńskim, por. J. Szczepaniak, Spis prepozytów i plebanów diecezji krakowskiej (XVIII w.), Kraków 2008, s. 124. Prawdopodobnie był to wymieniany przez J. Szczepaniaka Gasparus Kucewic (Kuczowic, Kuczewicz), wyświęcony w diecezji krakowskiej 27 maja 1745 i skierowany do pracy duszpasterskiej w parafii Piotrowice w dekanacie Zator, por. J. Szczepaniak, Katalog duchowieństwa diecezjalnego zestawiony na podstawie krakowskich ksiąg święceń (1646-1789), t. 2: J-M, Kraków 2008, s. 567.

${ }^{100}$ De Dote Ecclesiae seu Reditibus (łac.) - Odnośnie uposażenia lub dochodów.

${ }^{101}$ J. Długosz, Liber beneficiorum dioecesis Cracoviensis, t. 2: Ecclesiae parochiales, w: Joannis Dlugosz Senioris, Opera omnia, t. 8, cura A. Przezdziecki edita, Cracoviae 1864, p. 198. 
1529. Liber Retaxationum ${ }^{102}$.

1595. Wizyta Kazmierskiego własność kościoła opisuje ${ }^{103}$.

Pola Plebańskie Poświętne nazwane.

Od murowanej Bożej Męki na przedmieściu czeladzkim, przy publicznej drodze bytomskiej na południe leżące nad Brynnicą rzeką. Pola, więcej niż na ćwierc mili dobre wzdłuż, aż do granic wsi Milejowice, ale przez wydarcie dziedziców wsi Dąbrówka Celari ${ }^{104}$, tylko się teraz do granic Osiecza nazwanych rozciągają. Szerokość tych pól od rzeki Brynnica do drogi boguckiej rościąga się.

Ma pleban sadzawkę większą, Zatok nazwaną, przy rzece Brynnica blisko folwarku, ale od obywatelów miasteczka wydarta, od której sadzawki początek swój biorą łąki, z obu stron rzeki Brynnica ciągnące się do grobli łąk wojtowskich. Z tych łąk może być wozów czterokonnych 25 .

Ma pasze w swoich polach przy Sosninie do folwarku nalezącej.

Ma spolną paszę przy Grabku, a to dla Gor należących do pola plebań[skiego] ${ }^{105}$.

${ }^{102}$ Księga dochodów beneficjów diecezji krakowskiej z roku 1529 (tzw. Liber Retaxationum), wyd. Z. Leszczyńska-Skrętowa, Wrocław 1968, s. 260

${ }^{103}$ Wizyta Kazmierskiego - wizytacja kanoniczna parafii dekanatów pszczyńskiego i bytomskiego dokonana w 1598 r. na polecenie biskupa krakowskiego Jerzego kardynała Radziwiłła, przez ks. Krzysztofa Kaźmierskiego (Kazimierski), archidiakona krakowskiego, prepozyta tarnowskiego i późniejszego biskupa kijowskiego; por. Akta wizytacji dekanatów bytomskiego i pszczyńskiego dokonanej w roku 1598 z polecenia Jerzego kardynała Radziwiłta biskupa krakowskiego, wydał, wstępem i objaśnieniami zaopatrzył M. Wojtas, Katowice 1938; F. Maroń. Materiały źródtowe do dziejów Kościoła w obecnej diecezji katowickiej. Dekrety egzekucyjne do protokołów wizytacyjnych z r. 1598, „Śląskie Studia Historyczno-Teologiczne”, 5 (1972) s. 263-274.

${ }^{104}$ Cellari - rodzina krakowska pochodzenia włoskiego osiadła w Krakowie od końca XVI wieku; 16 lipca 1667 roku Jakub z Czarnocina Czarnowski zwany Celary zakupił dobra Dąbrówka, co dało początek długoletniej zmianie nazwy osady na Celary-Dąbrówka; por. K. Follprecht, Przyczynki do dziejów krakowskiego rodu Cellarich, „Krakowski Rocznik Archiwalny”, 5 (1999) s. 69-84; Dąbrówka Celarego, http://dabrowkamala.blogspot.com/2013/02/dabrowka-celarego.html (dostęp: 15.12.2017).

${ }^{105}$ Zdanie zapisano w podanej formie. 

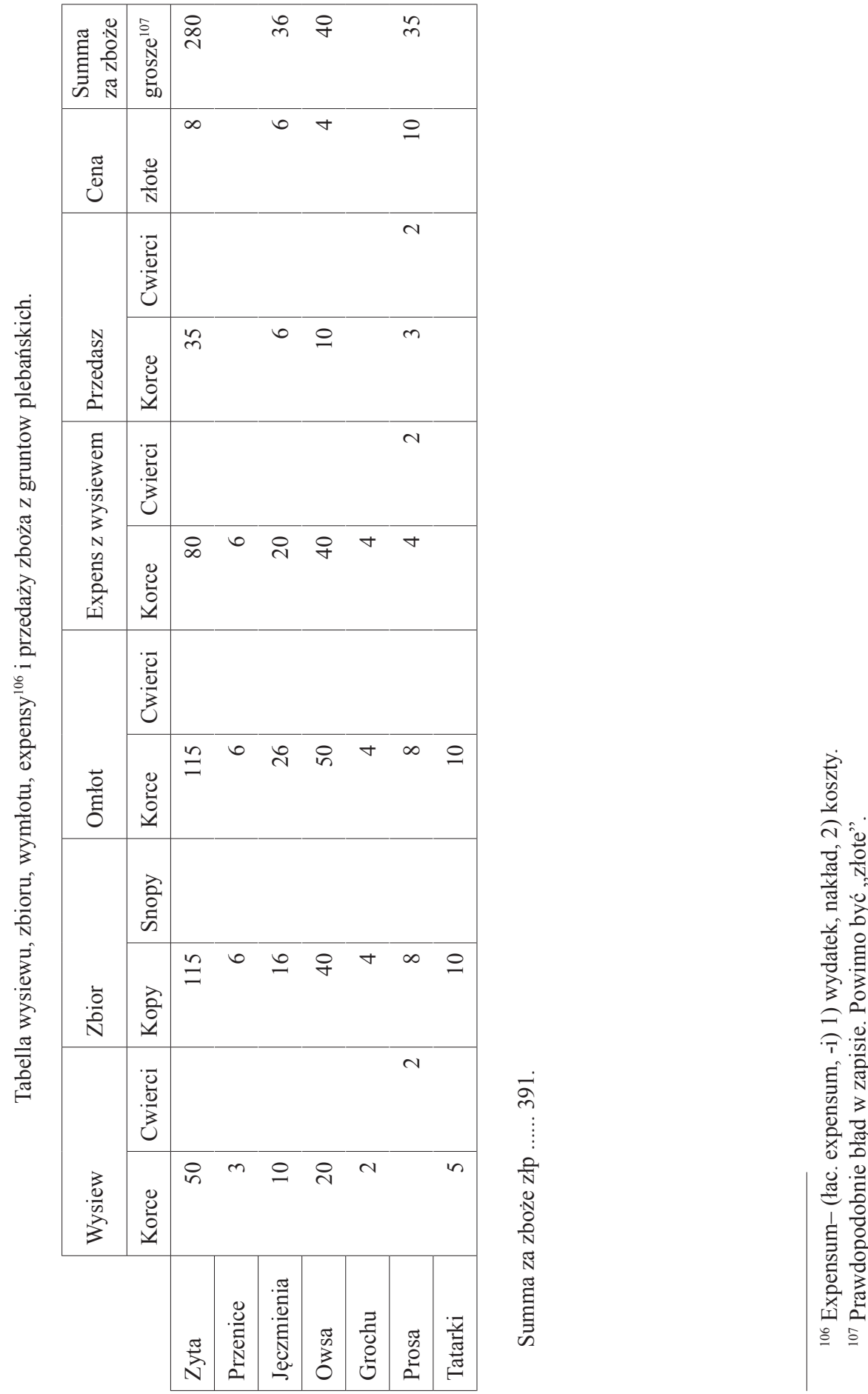
Dziesięciny wytyczne

[s. 260]

Złote

Dworska przełajska wozi się swemi końmi na folwark plebana czeladzkiego,

cena 100

Od kuźnikow przełajski . 20

Z niwy wójtowskiej czeladzkiej odwożona od wójta na folwark 40

Z Rozdzinia, chłopska, we wsi składana, połowa słomy 200

Z Sielca, chłopska, we wsi składana, połowa słomy 200

Z Zagorza, chłopska, we wsi składana, połowa słomy 400

Z Klimontowa, chłopska, we wsi składana, połowa słomy 300

Od młynarza czeladzkiego z odwozem 20

Z Dębia alternatim ${ }^{108} \mathrm{z}$ Zamkiem Siewierskim f. pol. 16

Summa za dziesięciny f. pol. 1296

Meszne czyli osep ${ }^{109}$

$\mathrm{Z}$ miasta Czeladzi wierteli ${ }^{110}$ siewierskich żyta $30-20$

owsa $150-100$

Z wójtostwa czeladzkiego żyta .. 2

Ze wsi Woykowic Komornych owsa 10

Ze wsi Woykowic Komornych żyta 36

Ze wsi Siemianowic owsa .................. 56

Ze wsi Przełayka ............................................................ owsa 28

żyta 15

$\mathrm{Z}$ dworu milowskiego

owsa 24

Ze wsi Milowic żyta 12

Ze wsi Milowic ... owsa 12

Żyta ze wszystkiego mesznego wierteli siewierskich żyta .. 8 ktore wynoszą na miarę krakowską korcy owsa 8 korzec rachując po f. pol 8 uczyni f. pol. 102 , Owsa ze wszystkiego mesznego wierteli siewier[skich] ..... 68 ktore wynoszą na miarę krakow[ską] korcy ..... 544. korzec rachuiąc po f. pol. 4 uczyni f. pol. 288 , Summa mesznego wierteli siewierskich żyta i owsa ... 192 768. na korce krakowskie 390 za ktore uczyni z. pol. 260 , 1312

\footnotetext{
${ }^{108}$ Alternatim (łac.) - na przemian, na zmianę.

109 Meszne, osep - termin określający rodzaj dziesięciny uiszczanej plebanowi w postaci wymłóconego już ziarna.

${ }^{110}$ Wiertel, viertl - miara pojemności ciał sypkich, używana głównie w krajach niemieckojęzycznych oraz pod zaborem austriackim i niemieckim; równa z polską ćwiercią; dla przykładu ćwierć warszawska = 30,151289 litra; tutaj odmiana tej miary pod nazwą ,wiertel siewierski”.
} 
$\mathrm{Z}$ miasta Columbationis ${ }^{111}$ f. pol.

Summa summarum $^{112}$ f. pol. 1329 gr 2

Intrata roczna

Za zboże sprzedane z grontów plebańskich jako wyżej f. pol.

Za dziesięciny ogólnie wszystkie f. pol. 391

Za ospy z miasta i wsiów 1296

Summa rocznej intraty 1329 gr 2

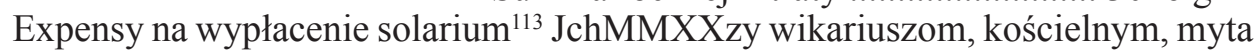
czeladzi, na utrzymanie sprzętow zakrystyi i gospodarskich i na inne nieuchronne potrzeby f. pol. 1500 .

Zostaje na pleba. 1516 gr 2

Inwentarz ekonomiczny, lubo bardzo szczupły odebrałem, za otaksowany wartał tylko cały złp 200, chcąc jednak uczynić dobrze temu miejscu z swoich własnych pieniędzy dodać obowięzuje się złp 300, a za tym miejscowy inwentarz wartać będzie złp 500 .

Wysiew lubo daleko mniejszy odebrałem, takowy jednak zostawić przyrzekam, jakowy jest w Tabelli wyżej opisany.

De Archivo Ecclesiae ${ }^{114}$

Archiwum kościoła w zakrystyi jest. Skrzynia, w której się papiery kościelne, processa i księgi pod dobrym zamknięciem chowają. Także i biblioteczka szczupluchna w kilkunastu książkach staroświeckich zaopatrzona mieści się. Jest i w zakrystyi skarbiec na srebro, kielichy i monstrancje pod dobrym zamknięciem.

De Parocho et aliis Presbyteris ${ }^{115}$

Pleban kościoła tego ksiądz Wawrzyniec Hechthaus ${ }^{116}$, urodzony Roku Pańskiego 1722. Dnia 10 sierpnia w mieście Wałczu w diecezyi poznańskiej M[inoris] O[r-

${ }^{111}$ Columbationis - (łac. columbatio, -nis) kolęda, okolicznościowa danina składana w okresie Bożego Narodzenia.

${ }^{112}$ Summa summarum (łac.) - całość.

${ }^{113}$ Salarium - (łac. salarium, -ii; solarium, -ii) wynagrodzenie.

${ }^{114}$ De Archivo Ecclesiae (łac.) - Odnośnie archiwum kościelnego.

${ }^{115}$ De Parocho et aliis Presbyteris (łac.) - Odnośnie Proboszcza i innych duchownych.

${ }^{116}$ Ks. Wawrzyniec Hechthaus (Hektauz) (1722-1800) - od 5 VII 1777 do 10 II 1800 r. pleban w Czeladzi. Około 1795 r. ks. W. Hechthauz został tknięty paraliżem, przez co stracił mowę. Dnia 18 sierpnia 1798 r. w obecności władz miejskich Czeladzi zawarł umowę z ks. Janem Szaflarskim. Według jej postanowień zarząd parafii i jej majątku oraz duchowa troska o wiernych został powierzony temu ostatniemu w zamian za dożywotnią opiekę nad ks. W. Hechthazuem i jego siostrą. Szczepaniak, Spis prepozytów, s. 51; Jedynak, Drabina, Stosunki wyznaniowe, s. 244-245; AKMKr, Akta parafialne, sygn. APC 6, Umowa pomiędzy ks. W. Hechthauzem a ks. J. Szaflarskim (Czeladź, 18 sierpnia 1798). 
dinis] clericus cum dimissoriii ${ }^{117}$. Poświęcony na kapłaństwo w Krakowie przez JW JMci Księdza Franciszka Potkańskiego ${ }^{118}$ Suffragana i Officjała Krak[owskiego] R. P. 1764, dnia 17 Marca. Instytuowany na tę plebanię w Krakowie w sądach zadwornych. R. P. 1777, dnia 5 Lipca, za prezentą J. O. Kajetana Sołtyka ${ }^{119}$ Ks[ięcia]cia Siewierskiego Biskupa Krakowskiego. Approbowany do słuchania spowiedzi w Krakowie w sądach zadwornych R. P. 1790, dnia 9 października na lat trzy. Zawsze przy kościele mieszkający.

Prebendarz, czyli pierwszy wikariusz przy tym kościele, ks. Piotr Rączkowski ${ }^{120}$, urodzony R. P. 1759, dnia 5 lipca w Śląsku w diecezyi krakow[skiej]. Poświęcony na kapłaństwo w Krak[owie], przez J. O. Ks[cia]cia Krzysztofa Hilarego Szembeka ${ }^{121}$ biskupa płockiego R. P. 1782, dnia 28 lipca. Instytuowany na prebendę w Krakowie in Officio Episcopali ${ }^{122}$ R. P. 1784, dnia 20 stycznia za prezentą Sław[etnych] mieszczan[ów] czeladzkich.

${ }^{117}$ Minoris Ordinis clericus cum dimissoriis (łac.) - kleryk posiadający niższe święcenia praz pismo zwane dymisorie, wystawione przez odpowiednie władze kościelne, a zezwalające na przyjęcie święceń kapłańskich.

${ }^{118}$ Franciszek Potkański (Podkański) (1708-1789) - 1753-1786 biskup sufragan diecezji krakowskiej, 1759-1783 oficjał i wikariusz generalny diecezji krakowskiej, por. W. Baczkowska, W. Szczygielski, Potkański (Podkański) Franciszek h. Brochwicz (ok. 1700-1789), biskup sufragan krakowski, w: Polski Stownik Biograficzny, t. 27, Wrocław 1982, s. 722-724; T. Graff, Podkański, Podkański Franciszek (ok. 1798-1789), w: Encyklopedia katolicka, t. 16, red. E. Gigilewicz, Lublin 2012, kol. 103-104.

${ }^{119}$ Kajetan Ignacy Sołtyk (1715-1788) - 1749-1756 biskup koadiutor kijowski, 1756-1759 biskup ordynariusz kijowski; 1759-1788 biskup ordynariusz krakowski, por. M. Czeppe, Sołtyk Kajetan Ignacy h. własnego (1715-1788), biskup krakowski, zesłaniec, w: Polski Słownik Biograficzny, t. 40 (2000), s. 386-404; J. Kuś, Sołtyk Kajetan Ignacy (1715-1788), w: Encyklopedia katolicka, t. 18, red. E. Gigilewicz, Lublin 2013, kol. 591-592.

${ }^{120}$ Piotr Rączkowski (5 VII 1759 - 20 VIII 1818) - 1795-1818 - proboszcz parafii pw. Trójcy Przenajświętszej w Chełmie [Śląskim]; urodził się 9 lipca 1759 w Biskupicach; od 1784 r. był wikariuszem przy kościele św. Stanisława w Czeladzi; 20 lipca 1816 gościł w Chełmie biskupa krakowskiego Jana Pawła Woronicza, udającego się na kurację do Karslbadu; jest autorem kroniki parafialnej zatytułowanej Documenta aliaque additamenta historiam villae et Ecclesiae chełmensis, w której zebrał i zacytował najważniejsze dokumenty do dziejów parafii w Chełmie; zmarł 20 sierpnia 1818 w Chełmie i tam został pochowany; por. J. Myszor, H. Dudała, Duchowieństwo parafialne, w: Chetm Śląski. Monografia gminy i parafii, red. J. Myszor, Chełm Śląski 2014, s. 265-266.

${ }^{121}$ Krzysztof Hilary Szembek (1723-1797) - 1785-1797 biskup płocki, por. R. Butterwick, M. Czeppe, T. Żebrowski, Szembek Krzysztof Hilary h. własnego (1723-1797), biskup płocki, w: Polski Stownik Biograficzny, t. 48, Warszawa 2012, s. 93-100.

122 in Officio Episcopali (łac.) - w Kurii (Urzędzie) Biskupiej. 
Wikariusz drugi ks. Piotr Schmołka ${ }^{123}$ urodzony w Śląsku w diecezyi krak[owskiej] R. P. 1761, dnia 29 czerwca. Poświęcony na kapłaństwo R. P. 1790, dnia 18 września, przez Jaśnie W. Jmci Księdza Józefa Olechowskiego ${ }^{124}$ suffragana i officjała krak[owskiego]. Aplicatus ${ }^{125}$ temu kościołowi w sądach zadwornych R. P. 1790, dnia 20 września. Obydwa do słuchania spowiedzi approbowani, którzy curam animarum ${ }^{126}$ utrzymują.

\section{De Schola Parochiali ${ }^{127}$}

Szkółki własnej nie masz, tylko obywatele najmują stancją do uczenia dzieci, których profesorem jest człowiek świecki od miasteczka pensjonowany.

Kierchowow ${ }^{128}$ i szkół żydowskich w tej parafii nie masz.

Klasztory. Zakonników i zakonnic nie znajdują się.

Opisanie Szpitala wyżej. Dochód ubóstwa bardzo szczupły. Z miasteczka i Pogoni dóbr złp 64. Promotor i starsi Bractwa ś. Anny ubogiemi dysponują.

Kaplica znajduje się prywatna w Pałacu JM Pana Lazara Henkla grafa bytomskiego w Siemianowicach w Śląsku, który Pan trzyma zakonnika Ord. S. Francisci Conventualium $^{129}$.

$\mathrm{W}$ tej parafii nie masz nic takowego z obyczajów, co by godne było doniesienia.

\section{De Solario Vicariorum Ecclesiae Czeladiensis}

Hoc tempore Commendarius Czeladiensis, nullum adhuc fixum determinatum habet Solarium, cum pro eodem assignatio Pensionis dependet vel a Commissione hic futura, vel ab Ill[ustriss]imo Officio Vratislaviensi. Alter Vicarius ejusdem Ecclesiae habet pro Solario, et Victu sibi assignatum flo. pol. 300 annuatim, participat etiam de accidentiis Ecclesiae 4tam partem, insuper Missas omnes liberas habet ${ }^{130}$.

${ }^{123}$ Piotr Schmołka (Smolke, Schmolke, Smołka, Schmołko) - urodził się prawdopodobnie w Siemianowicach; jego rodzicami byli Henryk i Agnieszka z Janotów; jego ojciec był leśniczym i dzierżawcą karczmy w służbie hrabiego Łazarza Henckel von Donersmarck; 1798-1804 proboszcz parafii w Radzionkowie, prezentę na probostwo uzyskał od kolatora parafii radzionkowskiej hr. Łazarza Henckel von Donersmarck; ze względu na słaby stan zdrowia często zastępowany był przez innych kapłanów - franciszkanów; zmarł w 1804 r. na tyfus; jego ciało pochowano przed wejściem do kościoła w Radzionkowie. Por. J. Szczepaniak, Katalog duchowieństwa diecezjalnego, t. 3: N-S, Kraków 2008, s. 1057; tenże, Spis prepozytów, s. 55; J. Knosała, Parafia Radzionkowska i jej dzisiejsze stosunki, Katowice 1926, s. 194-195.

${ }^{124}$ Józef Olechowski (1735-1806) - 1786-1806 biskup sufragan krakowski; por. W.M. Bartel, Olechowski (pierwotne nazwisko Oleszko, Olesek) Józef h. Ratuld (1735-1806), archidiakon i sufragan krakowski, w: Polski Stownik Biograficzny, t. 23, Wrocław 1978, s. 738-739; A. Szczerba, Duchowieństwo krakowskie w latach 1795-1918, Warszawa 2017, s. 743-744.

${ }^{125}$ Applicatus (łac.) - wyznaczony, naznaczony.

${ }^{126}$ Curam animarum (łac.) - troska o dusze, duszpasterstwo.

${ }^{127}$ De Schola Parochiali (łac.) - Odnośnie szkoły parafialnej.

${ }^{128}$ Kierchow (starop.) - cmentarz (zwłaszcza żydowski).

${ }^{129}$ Ord. S. Francisci Conventualium (łac.) - Ordini Sancti Francisci; właściwa nazwa: Ordo Fratrum Minorum Conventualium

${ }^{130} \mathrm{O}$ zapłacie dla wikariuszy kościoła w Czeladzi. W tym czasie zarządca czeladzki nie miał jeszcze do tej pory stałej przyznanej zapłaty, ponieważ przyznanie tego wynagrodzenia zależy w przy- 


\section{REFERENCES / BIBLIOGRAFIA}

\section{Źródła}

\section{Archiwalia}

Archiwum Archidiecezji Częstochowskiej (AACz)

Akta Konsystorza Kieleckiego, syg. KK 70: Akta Konsystorza Generalnego części diecezji krakowskiej w Królestwie Polskim tyczące się kościoła w Czeladzi 1791-1924. Archiwum Kurii Metropolitalnej w Krakowie (AKMKr)

Akta parafialne: sygn. APC 6.

\section{Źródla drukowane}

Akta wizytacji dekanatów bytomskiego i pszczyńskiego dokonanej w roku 1598 z polecenia Jerzego kardynała Radziwitła biskupa krakowskiego, wydał, wstępem i objaśnieniami zaopatrzył M. Wojtas, Katowice 1938.

Długosz Jan, Liber beneficiorum dioecesis cracoviensis, t. 2: Ecclesiae parochiales, w: Joannis Długosz Senioris, Opera omnia, t. 8, cura A. Przezdziecki edita, Cracoviae 1864.

Filozof Tomasz J., Nieznany inwentarz parafii staromiejskiej z 1819 roku, „Prace Historyczno-Archiwalne", 14 (2004) s. 155-159.

Janakowski Marcin, Inwentarz kościoła parafialnego w Chlewiskach z lat 1865-1866, „Z Dziejów Regionu i Miasta”, 6 (2015) s. 119-151.

Kaczmarek Agata, Młyńska Agata, Źródta do dziejów parafii w Szadku z roku 1825 - wizyta dziekańska i inwentarz parafialny, „Biuletyn Szadkowski”, 10 (2010) s. 199-217.

Księga dochodów beneficjów diecezji krakowskiej z roku 1529 (tzw. Liber Retaxationum), wyd. Z. Leszczyńska-Skrętowa, Wrocław 1968.

Maroń Franciszek, Materiały źródłowe do dziejów Kościoła w obecnej diecezji katowickiej. Dekrety egzekucyjne do protokołów wizytacyjnych z r. 1598, „Śląskie Studia Historyczno-Teologiczne", 5 (1972) s. 263-274.

Protokoły wizytacyjne dekanatu bytomskiego z lat 1792-1793, wydał J. Pater, Poznań -Wrocław 2003.

Szczepaniak Jan, Katalog duchowieństwa diecezjalnego zestawiony na podstawie krakowskich ksiąg święceń (1646-1789), t. 2: J-M, Kraków 2008.

Szczepaniak Jan, Katalog duchowieństwa diecezjalnego zestawiony na podstawie krakowskich ksiąg święceń (1646-1789), t. 3: N-S, Kraków 2008.

Szczepaniak Jan, Spis prepozytów i plebanów diecezji krakowskiej (XVIII w.), Kraków 2008.

Taszycka Maria, Inwentarz szat liturgicznych i innych tkanin zabytkowych z kościoła św. Marka w Krakowie, „Nasza Przeszłość”, 71 (1989) s. 115-136.

Trąba Mariusz, Czeladź w latach II wojny światowej (1939-1945). Źródła i materiaty z archiwów kościelnych, Katowice 2011.

Weiss Anzelm, Akta wizytacyjne parafii Wolsztyn z 1777 roku, Lublin 2019.

Żuraszek-Ryś Iwona, Inwentarz skarbca katedry ormiańskiej we Lwowie z XVIII wieku jako źródło do leksykologii historycznej, „Acta Universitatis Lodziensis. Folia Linquistica", 49 (2015) s. 115-124.

szłości albo od komisji, albo od Najjaśniejszego Urzędu we Wrocławiu. Następny wikariusz tego Kościoła ma przyznane na swoje wynagrodzenie i utrzymanie 300 florenów polskich co roku; pobiera także z przynależności kościelnych czwartą część; poza tym wszystkie opłaty za msze należą do niego (tłum. B. Machowska-Jaros). 
Żurek Waldemar W., Inwentarz kościoła parafialnego w Kiwatyczach z1853 roku, „Archiwa, Biblioteki i Muzea Kościelne”, 99 (2013) s. 317-333.

Żurek Waldemar W., Inwentarz parafii Świętego Michała Archanioła w Iwieńcu z 1939 roku, „Resovia Sacra”, 21 (2014) s. 503-531.

Żurek Waldemar W., Wizytacja kościoła parafialnego $w$ Dywinie w diecezji wileńskiej z 1867 roku, „Nasza Przeszłość”, 126 (2016) s. 265-290.

Żurek Waldemar W., Wizytacja kościoła parafialnego $w$ Kosowie z 1844 roku, „Nasza Przeszłość", 124 (2015) s. 137-164.

\section{Opracowania}

Baczkowska Wanda, Szczygielski Wacław, Potkański (Podkański) Franciszek h. Brochwicz (ok. 1700-1789), biskup sufragan krakowski, w: Polski Stownik Biograficzny, t. 27, Wrocław 1982, s. 722-724.

Bartel Wojciech M., Olechowski (pierwotne nazwisko Oleszko, Olesek) Józef h. Ratułd (1735-1806), archidiakon i sufragan krakowski, w: Polski Słownik Biograficzny, t. 23, Wrocław 1978, s. 738-739.

Brykczyński Antoni, Dom Boży to jest praktyczne wskazówki budowania, naprawiania i utrzymywania kościołów na wzór dzieła X. Montault „, Traité prtique de la construction, de l'ameublement et de la décoration des églises", Warszawa 1888.

Butterwick Richard, Czeppe Maria, Żebrowski Tadeusz, Szembek Krzysztof Hilary h. własnego (1723-1797), biskup płocki, w: Polski Stownik Biograficzny, t. 48, Warszawa 2012, s. 93-100.

Chmiel Adam, Domy krakowskie. Ulica św. Jana, Kraków 1924.

Czeppe Maria, Sołtyk Kajetan Ignacy h. własnego (1715-1788), biskup krakowski, zesłaniec, w: Polski Słownik Biograficzny, t. 40, Kraków 2000, s. 386-404.

„Dawno temu w Czeladzi...” Wystawa fotografii wedtug koncepcji artystycznej Jerzego Żymirskiego, Czeladź 2002.

Dąbrówka Celarego, http://dabrowkamala.blogspot.com/2013/02/dabrowka-celarego.html (dostęp: 15.12.2017).

Follprecht Kamila, Przyczynki do dziejów krakowskiego rodu Cellarich, „Krakowski Rocznik Archiwalny", 5 (1999) s. 69-84.

Graff Tomasz, Podkański, Podkański Franciszek (ok. 1798-1789), w: Encyklopedia katolicka, t. 16, red. E. Gigilewicz, Lublin 2012, kol. 103-104.

Historia Czeladzi, t. 1-2, red. J. Drabina, Czeladź 2012.

Instrukcja wydawnicza dla źródeł historycznych od XVI do połowy XIX wieku, red. K. Lepszy, Wrocław 1953.

Jedynak Zdzisław, Drabina Jan, Czeladź w XVII i XVIII wieku, w: Historia Czeladzi, t. 1, red. J. Drabina, Czeladź 2012, s. 201-272.

Karkocha Małgorzata, Wystrój $i$ wyposażenie kościoła parafialnego w Małogoszczu $w$ świetle inwentarza z 1856 roku, „Przegląd Nauk Historycznych”, 16 (2017) z. 1, s. $325-362$.

Knosała Józef, Parafia Radzionkowska i jej dzisiejsze stosunki, Katowice 1926.

Kostro Tomasz, Zagłębie którego nie ma. Będzin-Czeladź-Dąbrowa-Sosnowiec, Łódź 2017.

Kumor Bolesław, Dzieje diecezji krakowskiej do roku 1795, t. 1, Kraków 1998.

Kumor Bolesław, Dzieje diecezji krakowskiej do roku 1795, t. 4, Kraków 2002.

Kuś Jan, Sottyk Kajetan Ignacy (1715-1788), w: Encyklopedia katolicka, t. 18, red. E. Gigilewicz, Lublin 2013, kol. 591-592.

Kuzio-Podrucki Arkadiusz, Henckel von Donnersmarckowie-kariera i fortuna rodu, Bytom 2003. 
Litak Stanisław, Kościół łaciński w Rzeczypospolitej około 1772 roku. Studium administracyjne, Lublin 1996.

Myszor Jerzy, Dudała Halina, Duchowieństwo parafialne, w: Chetm Śląski. Monografia gminy i parafii, red. J. Myszor, Chełm Śląski 2014², s. 263-277.

Nawrot Dariusz, Powstanie na Nowym Ślasku w 1806 i 1807 roku. U źródet Zagtębia Dąbrowskiego, Czeladź 2016.

Nawrot Dariusz, W latach burzliwych zmian politycznych (1795-1831), w: Historia Czeladzi, t. 1, red. J. Drabina, Czeladź 2012, s. 275-312.

Rajman Jerzy, Czeladź do końca XVI wieku, w: Historia Czeladzi, t. 1, red. J. Drabina, Czeladź 2012, s. 75-200.

Rejdak Artur, Czeladź w latach II wojny światowej (1939-1945) ks. Mariusza Trąby. Sprostowania i uwagi, „Zeszyty Czeladzie”, 17 (2012) s. 45-50.

Ryszka Czesław, Klejnot Czeladzi. Kościót św. Stanisława Biskupa i Męczennika, Bytom 1997.

Sarna Kazimierz, Czeladź. Zarys rozwoju miasta, Katowice 1977.

Szczerba Anna, Duchowieństwo krakowskie w latach 1795-1918, Warszawa 2017.

Szczepaniak Jan, Duchowieństwo diecezji krakowskiej w XVIII wieku. Studium propozograficzne, Kraków 2010.

Trąba Mariusz, Stosunki wyznaniowe, w: Historia Czeladzi, t. 1, red. J. Drabina, Czeladź 2012, s. 469-522.

Turnau Irena, Słownik ubiorów, tkanin, wyrobów pozatkackich, skóry, broń i klejnoty znane w Polsce od średniowiecza do poczatku XIX w., Warszawa 1999.

Wiśniewski Jan, Diecezja częstochowska. Opis historyczny kościołów i zabytków $w$ dekanatach: będzińskim, dąbrowskim, saczowskim, zawierckim i żareckim oraz parafii Olsztyn, Marjówka Opoczyńska 1936.

Wlaźlak Władysław, Inwentarz ksiag konsystorskich Archiwum Archidiecezji Częstochowskiej im. ks. Walentego Patykiewicza w Częstochowie, ,, Rocznik Towarzystwa Genealogicznego Ziemi Częstochowskiej”, 2 (2011) s. 111-138.

Wlaźlak Władysław, Komisariat Siewierski w diecezji wrocławskiej (1797-1818), „Śląski Kwartalnik Historyczny Sobótka", 58 (2003) z. 3, s. 257-272.

Wlaźlak Władysław, Zasoby akt konsystorskich w Archiwum Archidiecezji Częstochowskiej, „Częstochowskie Studia Teologiczne”, 33 (2005) s. 193-209.

Związek Jan, Przynależność kościelna pogranicza Wielko- i Małopolski ze Ślaskiem, „Prace Naukowe Wyższej Szkoły Pedagogicznej w Częstochowie”, seria: „Zeszyty Historyczne", 2 (1994) s. 53-97.

Związek Jan, Utrata jurysdykcji przez biskupów krakowskich na Nowym Śląsku i w okręgu częstochowskim, „Analecta Cracoviensia”, 32 (2000) s. 401-413.

Żelazny Krystian Zbigniew, Księstwo Siewierskie. Prawo i ustrój a zakres suwerenności względem Korony Królestwa Polskiego, Katowice 2016.

Żuraszek-Ryś Iwona, Który to ornat? O sposobach nominacji ornatów w inwentarzach skarbca archikatedralnego kościoła ormiańskiego we Lwowie, „Poznańskie Spotkania Językoznawcze", 23 (2012) s. 301-317.

Żuraszek-Ryś Iwona, Pudełko Srebrne do Hostyi bez przykrywadła. O sposobach określania przedmiotów w inwentarzach kościelnych, „Poznańskie Studia Polonistyczne. Seria Językoznawcza", 23 (2016) z. 1, s. 131-143.

Żuraszek-Ryś Iwona, Nazwy tkanin wschodniego pochodzenia w osiemnastowiecznej polszczyźnie (na przykladzie materiału $z$ dwóch inwentarzy skarbca archikatedralnego kościoła ormiańskiego we Lwowie), w: Kontakty językowe w komunikowaniu, red. M. Steciąg, M. Adamczyk, M. Biszczanik, Zielona Góra 2016, s. 137-147. 


\title{
THE PARISH OF ST. STANISLAUS THE BISHOP AND MARTYR IN CZELADŹ - A DESCRIPTION FROM 1791 (A FRAGMENT OF THE UNDISCOVERED REPORT FROM THE VISITATION OF THE SIEWIERZ DEANERY IN THE KRAKOW DIOCESE FROM THE 1890S)
}

\begin{abstract}
In 1846, Fr. Wojciech Janecki was installed as the parish priest of St. Stanislaus in Czeladź, only to find out that the parish did not have an up-to-date inventory of property and property rights. In search of this document, the parish turned to the General Consistory of the Diocese of Krakow. Despite investigation, such a list was nowhere to be found. The only document discovered in the Consistory Archives was a description of the town of Czeladź and the parish of Czeladź compiled in 1791. A copy of this document was sent to the Consistory of the Krakow Diocese in Kielce. This document is the subject of this study. Entitled "Opisanie Kościoła i Parafii Miasteczka Czeladź" ("Description of the Church and Parish of the Town of Czeladź"), the 1791 record is a part of a larger file from that period - perhaps a visitation of the Siewierz deanery. This can be inferred from its content and structure, which resembles documents of this type from the end of the 18th century, e.g. visitation records of the neighbouring Bytom deanery over the years 1792-1793. The thorough scrutiny of both church and state archives has not produced any positive results so far as to the sources confirming the said visitation.

The published document is one of the most important sources on the history of Czeladź in the final period of the Republic of Nobles. Its author provides detailed data both on the parish and the church in Czeladź in the last years before the partitions of Poland. It should be emphasised that this document has never been used before in the research on the history of Czeladź.
\end{abstract}

Keywords: parish of St. Stanislaus; pre-partition Poland; Siewierz deanery; Czeladź; 18th century; canonical visitation; Krakow Diocese 